\title{
Advances
}

Shiho Yukawa*

\section{Effects of Fatherhood on Male Wage and Labor Supply in Japan}

\begin{abstract}
Using data from the Japanese Panel Survey of Consumers (JPSC) for the period 1994-2007, I examine the effect of childbirth on fathers' wage rates and labor supply in Japan. I also compare the effects of fatherhood between different cohorts by dividing the JPSC sample into two birth-year cohorts (those born in or before 1960 and those born after 1960). The results show that the birth of children significantly increases hourly wage rates by $2.3 \%$ and annual work by 69 hours. Comparing these results to those of studies based in the United States and Germany shows that while the effect of childbirth on the Japanese male labor supply is large, it is relatively small on wage rates. The study also shows that childbirth has different impacts on labor market outcomes for the two cohorts. In the early cohort, the birth of children significantly increases wage rates, but has no significant effect on the labor supply. On the contrary, for the later cohort, the birth of children does not increase wage rates and there is a significant increase in the labor supply. Finally, I examine how the gender difference of children impacts labor market outcomes. Although its impact is not so large, the birth of sons has a larger effect than the birth of daughters.
\end{abstract}

Keywords: childbirth, labor supply, wage, cohort analysis

DOI 10.1515/bejeap-2013-0097

\section{Introduction}

How does the birth of children affect household labor supply and income? An increase in nursing time and childcare costs may strain a household budget, or reduce its time resource and affect intra-household specialization. Moreover, it is documented that many women leave the labor market after giving birth.

*Corresponding author: Shiho Yukawa, Faculty of Economics, Teikyo University, Hachioji, Tokyo, Japan, E-mail: s_yukawa@main.teikyo-u.ac.jp 
Indeed, many studies have analyzed the relationship between childbirth and female labor supply (i.e. Korenman and Neumark 1992; Waldfogel 1995, 1998; Lundberg and Rose 2000; Kawaguchi 2001) and found that the birth of children significantly decreases labor supply from women.

By contrast, this paper examines the impact of childbirth on the labor market outcomes of male workers in Japan. The study concerns itself with the impact of fatherhood on the labor market, because childbirth affects the intrahousehold division of labor; hence, it influences not just the labor supply and wages of wives but also those of their husbands. Since the labor market outcomes of husbands (rather than those of their wives) have a greater impact on the household budget for most families, we need to examine the effects of childbirth on husbands' labor supply and wages in order to precisely understand the total effect of childbirth on the household. In addition, the predicted changes in labor market outcomes after childbirth may also affect the fertility decisions of households. If a married couple expects stagnant earnings for the husband after childbirth, in spite of working longer hours, they may choose not to have many children. Therefore, the aim of this study is to clarify the effect of fatherhood on the labor market in Japan. Using the Japanese Panel Survey of Consumers (JPSC), I estimate the effects of childbirth on men's labor supply and hourly wage rates in Japan. I then compare the results with previous studies from the US (Lundberg and Rose 2002) and Germany (Choi et al. 2008).

The impact of childbirth on wages and labor supply should depend on the labor market environment facing each household. For instance, if the family allowance provided by firms (maternity leave benefits, type of employment contract, and expected wage growth), change labor supply behavior after childbirth. Since different countries have individual labor market practices and institutions, we can learn how the labor market environment affects worker behavior after childbirth, by comparing the estimated impacts of childbirth across countries. Japanese employment practices have several unique characteristics, such as lifetime employment, the seniority wage system, and substantial employee benefits. Therefore, adding evidence from the Japanese labor market to the literature advances our understanding of how labor market environments affect lifecycle decisions of the labor supply.

Besides a cross-country comparison, I also compare the estimated impact of childbirth across cohorts, as there have been drastic changes in the Japanese labor market during the past three decades. First, laws aiming to promote women's participation in the labor force have been enforced in this period (e.g. the Equal Employment Opportunity Law 1986 and Childcare Leave Law 1992). The Equal Employment Opportunity Law provides workers with equal opportunities in employment, regardless of sex. The Childcare Leave Law permits at most one year 
off from the job after childbirth. Additionally, it allows workers to extend childcare leave until the child is one and a half years old, in cases where the child cannot start nursery education, although the parents might wish it, and when the spouse who is the primary caregiver for the child finds it difficult to fulfill their duties due to reasons such as death and disease. After the enforcement of these new laws, the share of employed women increased from $35.9 \%$ in 1985 to $42.6 \%$ of the workforce in 2013 (Ministry of Internal Affairs and Communications Labor Force Survey). ${ }^{1}$ Thus, many women entered the labor market, and consequently the wage gap between males and females has been decreasing in Japan. ${ }^{2}$ The labor market participation of female workers and decrease in the gender wage gap may change the comparative advantages between husbands and wives, as well as their traditional gender roles.

Second, the long-term stagnation of the macro-economy during the 1990s often called the "lost decade" in Japan - altered the characteristics of the Japanese employment system to a certain degree. Figure 1 shows recent trends in the Japanese labor market. In the 1990s, the economic growth rate decreased, while the unemployment rate increased. In addition, the share of non-regular workers, who are usually not able to receive most of the benefits of Japanese employment practices, increased substantially during this period.

The novel feature of these drastic changes in the Japanese labor market is that their impact is substantially different across cohorts. Abe (2011) examined how the introduction of the Equal Employment Opportunity Law affected the female labor force and showed that the regular employment ratio of women did not increase in the cohorts who entered the labor market after the law was passed; specifically, the negative impact of stagnation was especially large in the younger cohorts. Figure 2 shows the male unemployment rate and the rate of non-regular male workers by age group. Both the unemployment rate and share of non-regular workers increased, especially for younger workers. Similarly, Kondo (2007) found that Japanese workers who failed to find regular jobs after graduation, have a considerably low probability of finding regular jobs afterwards. Genda et al. (2010) showed that the wage loss of less educated Japanese workers who graduated during the depression was persistent, whereas the wage loss of American workers who graduated at the same time was temporary.

Since different generations confront different labor market conditions, the effect of fatherhood on labor supply behavior might differ between older and younger

1 Several studies have examined the effect of the Equal Employment Opportunity Law on women's behavior. Edward and Pasquale (2003) suggested that the introduction of this Law increased the incidence of women pursuing higher education.

2 Kawaguchi (2005b) showed that an increase in the tenures of female workers have substantially contributed to a reduction in the gender wage gap. 


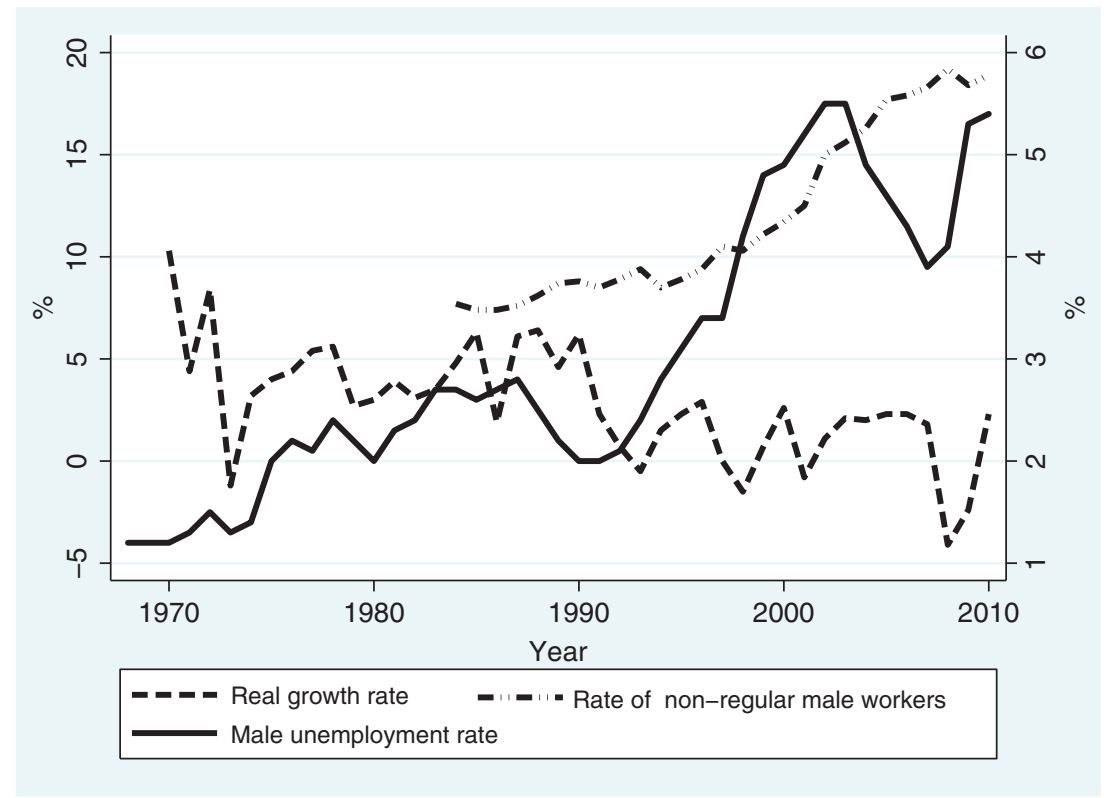

Figure 1: Trends in the Japanese labor market.

Note: Data for real growth rate and male unemployment rate are sourced from the System of National Accounts and the Japan Labor Force Survey, respectively. Data for rate of non-regular male workers are sourced from the Special Survey of the Labor Force Survey (1984-2001) and the Labor Force Survey since 2002 (Japan).

cohorts. In order to compare the estimated impact between cohorts, I divide the sample into two birth-year cohorts: those born in or before 1960 (early) and those born after 1960 (late). For workers born before 1960, the Equal Employment Opportunity Law had yet to be implemented when they entered the labor market, and the patriarchal view of the sexual division of labor within households was still dominant. ${ }^{3}$ Moreover, cohorts born before 1960 entered the labor market in a period when the Japanese economy was growing at sustainably high rates. Consequently, they had a sufficient number of employment opportunities, and most of them were able to get regular jobs. In a large part of their careers, they enjoyed large increases in wage, thanks to a favorable business environment and Japanese employment practices. The Japanese practice is characterized by long-term employment, and a

3 Nagase (1999) and Higuchi (2007) also compared labor supply behaviors or attitudes toward marriage across cohorts. Nagase (1999) showed that workers who found their first jobs after the implementation of the Equal Employment Opportunity Law tended to have a more liberalized view towards the sexual division of labor. 

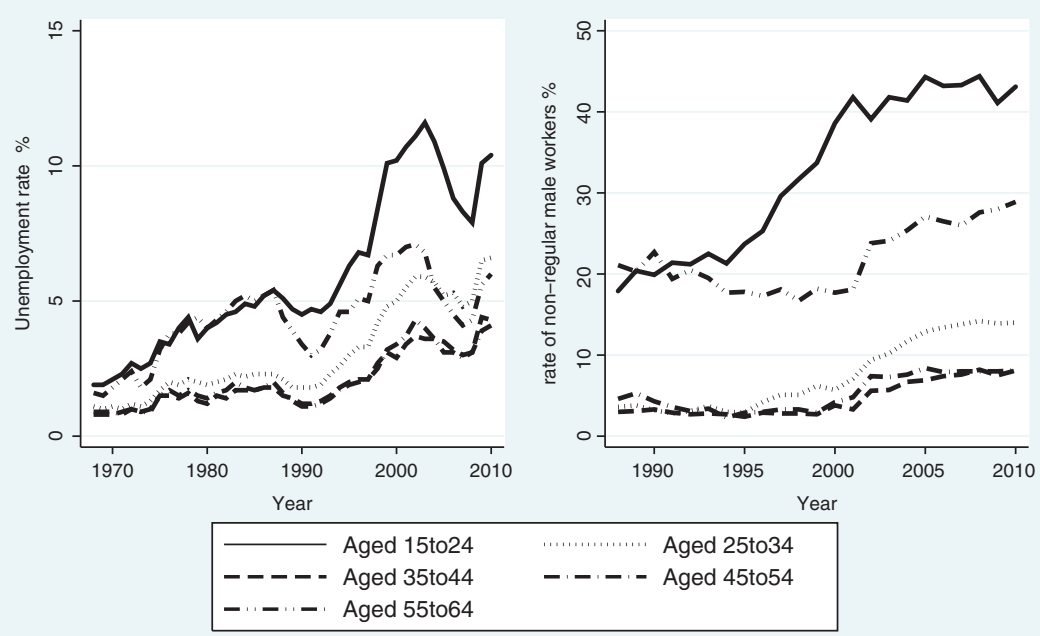

Figure 2: Male unemployment rate and rate of non-regular male workers by age group. Note: Data for male unemployment rate are sourced from the Japan Labor Force Survey. Data for rate of non-regular male workers are sourced from the Special Survey of the Labor Force Survey (1984-2001) and the Labor Force Survey since 2002 (Japan).

seniority wage system, while protecting employment security. On the other hand, the cohorts born after 1960 entered the labor market in a less favorable period. As explained earlier, the later cohorts enjoy fewer opportunities for regular employment than earlier cohorts did. Since there has been a permanent deficit in labor demand during the past several decades, workers in the later cohort have experienced less employment security for a large part of their careers.

By comparing the estimated impact of fatherhood between different cohorts, I can examine whether the difference in labor market environments or the change in the view of the sexual division of labor affects the relationship between childbirth and labor market outcomes. ${ }^{4}$

The main findings of this paper are as follows. The birth of children significantly increases hourly wage rates by $2.3 \%$ and annual work hours by 69 hours. A comparison of these results with those from the US (Lundberg and Rose 2002) and Germany (Choi et al. 2008) shows that while the effect of childbirth on labor supply is large in Japan, the effect on wage rates is relatively small. Moreover, childbirth has different impact on labor market outcomes for early and late

4 Although my criteria that split the sample into early and late cohorts are somewhat arbitrary, the main results do not change if I choose 1965 as the cutoff year (see the Appendix). 
cohorts. For the early cohort, the birth of children significantly increased wage rates, but has no significant effect on labor supply. On the contrary, for the later cohort, while the birth of children does not increase wage rates, there is a significant increase in labor supply.

An interesting result in Lundberg and Rose (2002) is that the birth of a son has a larger impact on male labor supply than the birth of a daughter. I examine whether the child's gender alters the impact of childbirth on labor supply in Japan. As a result, I find that the child's gender does not seem to have a significant effect on men's labor market outcomes in Japan.

Some recent studies have estimated the effect of childbirth on male labor supply and wages. Using data from the Panel Study of Income Dynamics, Lundberg and Rose (2000, 2002) showed that in the US, childbirth significantly increases both male labor supply and wages, and that the effect of childbirth differs among cohorts. They also found that childbirth has a large impact on the labor supply of male workers born after 1950, compared to earlier cohorts. One possible explanation is that while later cohorts are less specialized after marriage, childbirth promotes the sexual division of labor among these couples. Choi et al. (2008) used data from the German Socio-Economic Panel Study to show that childbirth has a positive impact on German male labor supply and their wages. While I provide a more detailed explanation of the methodology used in this study later, I follow the empirical approach presented by Lundberg and Rose (2002) and Choi et al. (2008) in order to compare the estimated impact of childbirth across countries.

In Japan, Kawaguchi (2005a) examined the effect of childbirth on a parent's wages by using data from the JPSC for the period 1993-2000. He found that the birth of children has a positive impact on wages of male workers, but that most of the impact disappears when the effect of time-invariant individual characteristics are controlled for. Although Kawaguchi's (2005a) findings are similar to the ideas in the present study, there are several important differences between them. First, I consider the impact of childbirth not only on wages but also on the labor supply of male workers. It is important to examine the response of labor supply to childbirth to understand how childbirth affects the division of labor in the household. Second, I examine the difference in the effect of childbirth among cohorts. I show that childbirth exerts different impacts across cohorts. Third, I examine how a difference in a child's gender affects male labor supply and wages.

\section{Theoretical hypotheses}

Theoretical prediction of the impact of childbirth on the labor market outcomes of their parents is not clear because childbirth has many potential impacts on 
the decisions of the household. I argue that there are four important effects of childbirth on the labor market outcomes of their fathers: specialization effect, intensity effect (negative) income effect, and family allowance pay effect. ${ }^{5}$

The specialization effect refers to the sexual division of labor in a family, and that women (men) start to spend more time at home (out at work) in order to exploit their comparative advantages (Becker 1985). Therefore, if the specialization effect is substantially large, the birth of children increases the labor supply of male workers. Moreover, if the division of labor involves productivity gains, the specialization effect also predicts an increase in the wage rates of husbands.

By contrast, childbirth reduces the time resource available to the household, since raising children is time consuming. This is called the intensity effect, which has a negative impact on male labor supply. The size of the intensity effect depends on how parents divide childcare and housework. If the time constraints also reduce job-training opportunities, then childbirth may have a negative effect on the wage rates of husbands.

If the pecuniary costs of childcare are high, childbirth will also decrease the available income for consumption by parents. In other words, childbirth has a negative income effect. If leisure is a normal good, the negative income effect due to childbirth will have a positive impact on male labor supply.

Childbirth automatically increases parents' disposable incomes, since many Japanese firms provide family allowance pay. As the JPSC has no information regarding family allowance pay, it is difficult to identify the "family allowance pay effect." Therefore, we must assume that family allowance pay is responsible for at least a portion of the estimated effect of childbirth on wage rates.

These discussions imply that the overall effect of childbirth on male labor supply and wages depends on the magnitude of each effect, and on the labor market environment. For instance, the relationship between productivity changes caused by the sexual division of labor, job training, and wage rates depends on the labor market system and prevailing practices. In a performance-based wage system, specialization effects forecast a large increase in wages. By contrast, in the seniority wage system, productivity changes may have little impact on wages. Since many Japanese firms adopt the seniority wage system, the wage impact of childbirth may be weaker in Japan as compared to other advanced countries. Moreover, workers may have little opportunity to adjust their labor supply after childbirth in rigid or stagnant labor markets. Therefore, cross-country dissimilarities in labor market characteristics, and inter-generational differences in the labor market environments faced by workers, can influence the effect of childbirth on male labor supply and

5 Lundberg and Rose (2002) argued that childbirth affects the labor market outcomes of parents, mainly owing to specialization effects and intensity effects. 
wages. For instance, if childbirth affects wages or the labor supply of male workers mainly through a change in jobs after childbirth, the impact of childbirth on labor market outcomes would depend on the degree of employee turnover in labor markets. Since the employee turnover rate is low in the Japanese labor market, the impact of childbirth would be small in Japan in this instance.

I aim to reveal these differences by comparing the estimated impact of childbirth, not only across countries but also across generations. The main contribution of this study is to provide comparable evidence about the effect of childbirth on Japanese male labor supply and wages. Given the theoretical prediction that the effects of childbirth depend on labor market environment and institutional employment practices, comparing the cross-country effects of childbirth could help us understand the relationship between childbirth and labor market outcomes. Since Japanese labor market conditions have changed drastically during the past decade, and economic stagnation has had different impacts on early and late cohorts, I think that it is also meaningful to compare the effects of childbirth between different cohorts.

\section{Data and identification strategy}

\subsection{Description of data}

I use JPSC data collected by the Institute for Research on Household Economics. The JPSC survey began in 1993 with a nationally representative sample of 1500 women aged from 24 to 34 years. Information on these women (and their husbands) has been collected continuously, including data covering employment, income, wealth, expenditures, health, marriage, childbearing, and numerous other topics. Moreover, samples of 500 women aged from 24 to 27 years were added in 1997 and 836 women aged from 24 to 29 years were added in 2003. I also use data on husbands who are married to the surveyed women. ${ }^{6,7}$ Although the JPSC is a survey of women and its main purpose is to investigate the lifestyles of women, the data also contain rich information on household characteristics, including the labor market outcomes of husbands, such as amount of labor supply, wage information on wives, number of children, and children's gender. Since the

\footnotetext{
6 My sample excludes children born outside wedlock, as such children are very rare in Japan; I do not believe this would pose a significant problem for our study.

7 If the women divorce and remarry with other men, only information on the current husband is reported. These have been dropped from the sample.
} 
first year of the survey (1993) did not collect data on the annual days of work and salaries, I use the corresponding data for the period between 1994 and 2007.

Table 1 presents summary statistics for my sample, comparing male workers born on or before 1960 (early cohort) with those born after 1960 (later cohort). ${ }^{8}$ The average number of children is $1.7 .^{9}$ The share of college graduates is larger in the early cohort, which may seem odd given the increased emphasis on education in later years. This may be because the college enrollment ratio of the cohort born in the early 1970s, who are the children of the "baby boomers" in Japan, is low. ${ }^{10,11}$ However, it does not necessarily imply a decline in education because the share of those who graduated from junior college, technical schools, or high schools is larger for the later cohorts, than for the early cohorts.

\subsection{Endogeneity problems and estimation strategy}

While my focus is on the relationship between the labor market outcome of married male workers and the number of children, it is likely that childbirth depends on various unobserved factors that are also correlated with labor market outcomes. For example, if unobservable individual characteristics, such as preference, personal traits, or innate ability affect both the labor market outcome and the number of children, the standard ordinary least squares (OLS) estimation cannot clarify the causal effect of childbirth on labor market performance. If the number of births depends on unobservable individual characteristics that also affect income and labor supply, it would be incorrect to interpret the correlation between the number of children born and the labor market outcome as a causal effect of childbirth on labor market performance.

8 Following Kondo (2008), I provide an explanation on the calculation procedure of the annual hours worked and hourly wage in the Appendix.

9 The distribution of the number of sons and daughters is provided in the Appendix. The number of sons is slightly larger than that of daughters in the sample. This may be due to preference for sons in households, or due to the sample selection bias that the fathers tend to be present if they have sons. (Kureishi and Wakabayashi (2011) find that preference for sons is observed only among cohorts born between 1920 and 1939 in Japan.) While the estimated impact may be biased if sex of children is endogenous, this endogeneity is not a serious problem for fixed effects estimator because the correlation between the probability of divorce and change in wages and labor supply after childbirth is not so strong.

10 For example, Abe (2012) showed that the share of male university graduates is somewhat low among those born in 1963-1977 compared with those born in 1958-1962.

11 I provide a detailed summary of statistics in the appendix, which show that the distribution of industry and occupations across cohorts do not differ greatly. 
Table 1: Summary statistics.

\begin{tabular}{|c|c|c|c|}
\hline & Full sample & Born in 1960 or earlier & Born after 1960 \\
\hline Hourly wage $^{a}$ & $\begin{array}{l}1590.858 \\
(585.637)\end{array}$ & $\begin{array}{r}1755.252 \\
(633.586)\end{array}$ & $\begin{array}{l}1508.475 \\
(541.651)\end{array}$ \\
\hline Log (real hourly) wage ${ }^{a}$ & $\begin{array}{r}7.293 \\
(0.361)\end{array}$ & $\begin{array}{r}7.389 \\
(0.375)\end{array}$ & $\begin{array}{r}7.245 \\
(0.345)\end{array}$ \\
\hline Annual hours worked & $\begin{array}{l}2615.784 \\
(727.531)\end{array}$ & $\begin{array}{r}2591.288 \\
(697.338)\end{array}$ & $\begin{array}{l}2627.948 \\
(741.806)\end{array}$ \\
\hline Number of children & $\begin{array}{r}1.718 \\
(0.978)\end{array}$ & $\begin{array}{r}2.038 \\
(0.883)\end{array}$ & $\begin{array}{r}1.559 \\
(0.983)\end{array}$ \\
\hline Number of boys & $\begin{array}{r}0.934 \\
(0.829)\end{array}$ & $\begin{array}{r}1.109 \\
(0.823)\end{array}$ & $\begin{array}{r}0.848 \\
(0.818)\end{array}$ \\
\hline Number of girls & $\begin{array}{r}0.784 \\
(0.789)\end{array}$ & $\begin{array}{r}0.931 \\
(0.807)\end{array}$ & $\begin{array}{r}0.710 \\
(0.769)\end{array}$ \\
\hline If first child is a boy ${ }^{b}$ & $\begin{array}{r}0.479 \\
(0.499)\end{array}$ & $\begin{array}{r}0.545 \\
(0.498)\end{array}$ & $\begin{array}{r}0.447 \\
(0.497)\end{array}$ \\
\hline If first child is a girl ${ }^{\mathbf{b}}$ & $\begin{array}{r}0.387 \\
(0.487)\end{array}$ & $\begin{array}{r}0.397 \\
(0.489)\end{array}$ & $\begin{array}{r}0.382 \\
(0.486)\end{array}$ \\
\hline At least one boy & $\begin{array}{r}0.660 \\
(0.474)\end{array}$ & $\begin{array}{r}0.756 \\
(0.429)\end{array}$ & $\begin{array}{r}0.611 \\
(0.487)\end{array}$ \\
\hline At least one girl & $\begin{array}{r}0.582 \\
(0.493)\end{array}$ & $\begin{array}{r}0.666 \\
(0.472)\end{array}$ & $\begin{array}{r}0.540 \\
(0.498)\end{array}$ \\
\hline Age & $\begin{array}{l}37.050 \\
(6.396)\end{array}$ & $\begin{array}{r}43.116 \\
(4.828)\end{array}$ & $\begin{array}{l}34.037 \\
(4.721)\end{array}$ \\
\hline Education $^{c}$ & & & \\
\hline Junior high school & $\begin{array}{r}0.096 \\
(0.295)\end{array}$ & $\begin{array}{r}0.105 \\
(0.307)\end{array}$ & $\begin{array}{l}0.0922 \\
(0.289)\end{array}$ \\
\hline High school & $\begin{array}{r}0.404 \\
(0.490)\end{array}$ & $\begin{array}{r}0.391 \\
(0.488)\end{array}$ & $\begin{array}{r}0.426 \\
(0.495)\end{array}$ \\
\hline Junior college or technical college & $\begin{array}{r}0.136 \\
(0.343)\end{array}$ & $\begin{array}{r}0.098 \\
(0.298)\end{array}$ & $\begin{array}{r}0.156 \\
(0.363)\end{array}$ \\
\hline University or graduate school & $\begin{array}{r}0.361 \\
(0.480)\end{array}$ & $\begin{array}{r}0.404 \\
(0.490)\end{array}$ & $\begin{array}{r}0.325 \\
(0.469)\end{array}$ \\
\hline Wife's employment status & $\begin{array}{r}0.521 \\
(0.499)\end{array}$ & $\begin{array}{r}0.597 \\
(0.490)\end{array}$ & $\begin{array}{r}0.483 \\
(0.499)\end{array}$ \\
\hline Number of observations & 12,872 & 4,271 & 8,601 \\
\hline
\end{tabular}


The previous literature deals with this endogeneity problem mainly by two methods. The first approach is to use instrumental variables (IV). If we can find instruments that are correlated with the number of children but not correlated with unobservable individual traits, we use these variables as IV and can gain consistent estimators. For example, Angrist and Evans (1998) used the sex composition of the first and the second child as an instrument for the number of children. While sex composition is randomly determined and thus, is not correlated with labor market outcomes of parents, the sex composition of children has a considerable effect on the number of children, given that it drives the parents' decision on whether to give birth to the third and any subsequent children. However, their IV can only be used to estimate the impact on the third and subsequent children. Thus, I do not adopt their method, as some of my samples have more than three children.

The second approach is to control the unobserved fixed effects (FE). If unobservable individual traits correlated with the number of children are time invariant, then by adding an individual specific term to the explanatory variables, I can control the effect of time invariant heterogeneity, and get a consistent estimator. Following Korenman and Neumark (1991), Waldfogel (1997), Lundberg and Rose (2002), and Choi et al. (2008), I adopt this approach to deal with the endogeneity problem. Although the FE method is standard in the literature, we should note that we might not remove the potential bias completely, even if we can control the time invariant traits. For example, if workers have children when they expect future wage growth, causality runs from the wage to the number of children. When the impact of expected wage growth on fertility decisions is not negligible, the FE estimator of impact on wages has a positive bias. Unfortunately, we cannot remove the impact of expectation on the wage growth, which is the limitation of the empirical method used here, and is shared by the abovementioned studies. Hence, we must interpret the estimated impact of childbirth on wage with caution. A similar argument can be applied to labor supply analysis, but I believe that the estimated impact on hours of work has little bias, because the hours of work are relatively stable in Japan.

\section{Estimation model}

Following Lundberg and Rose (2002), I examine several specifications of empirical models that allow for the possibility that the effect of childbirth on the male labor market outcome is nonlinear.

The benchmark linear specification is given as

$$
Y_{i t}=a_{i}+\beta N_{i t}+\beta_{4} D 4_{i t}+\gamma^{\prime} X_{i t}+u_{i t},
$$


where $Y_{i t}$ is a labor market outcome variable, that is, the log hourly wage or annual hours of work for worker $i$ in year $t$; $N_{i t}$ is the number of children, which takes zero if it exceeds three. The dummy $D 4_{i t}$ takes the value of one if a man has four or more children, and zero otherwise. ${ }^{12}$ The term $a_{i}$ represents the individual fixed effects and $X_{i t}$ is the vector of individual observable characteristics that includes age (dummy variable), education, industry, occupation, and firm size.

If individual fixed effects $\left(a_{i}\right)$ are correlated with number of children $N_{i t}$, standard OLS estimators that ignore individual fixed effects do not coincide with parameter $\beta$, which is the causal impact of childbirth. For example, when individuals with a high earning ability tend to have more children, $a_{i}$ is positively correlated with the number of children $N_{i t}$. In this case, OLS overestimates the impact of childbirth. On the contrary, if individuals with poor earning ability tend to have more children, OLS estimators have a negative bias, thereby underestimating the impact of childbirth. By controlling individual fixed effects, we can eliminate these possible biases.

There will be a difference between the impacts of the birth of the first and that of the second child. In order to assess such heterogeneity of impact, I also examine the nonlinear specification using the dummy variable $D_{j}$, which equals one if the number of children is $1 \leq j \leq 3$ and 0 otherwise, instead of the number of children.

I also examine the following four specifications to estimate the effects of the child's gender on labor market outcomes as shown in Table 6 and Table 7. (i) The first specification examines the impact of the number of boys and the number of daughters. (ii) The second specification aims to compare households with boys against those with girls. For this purpose, I estimate the impact of the variable called "at least one boy", which is a dummy variable that equals one if a man has at least one son and zero otherwise, and the variable called "at least one girl", which is a dummy variable that equals one if man has at least one daughter and zero otherwise. The gender composition of children may be endogenous if parents prefer a son or a daughter. (iii) To consider this problem, I also estimate the model to examine the effect of the gender of the first child, which is assumed to be perfectly random. The variable called "first child is a boy" equals one if a man has at least one son and the first child is a son and zero otherwise, and the variable called "first child is a girl" equals one if a man has at least one daughter and the first child is a daughter and zero otherwise. (iv) The nonlinear specification that distinguishes the birth of a boy from that of a girl is also examined by using dummy variables. I estimate all models by both OLS and FE estimators.

12 This specification follows Lundberg and Rose (2002). It assumes that the additional impact of childbirth is constant by the third child and the additional impact of the fourth or later child is zero. 


\section{Results}

\subsection{The effect of children on wage}

First, I examine the impact of fatherhood on wage. Table 2 presents the estimated effect of childbirth on wage in the total sample. Columns (1)-(4) report OLS estimators, and columns (5)-(8), FE estimators. I provide the results of the linear and nonlinear models. Columns (3), (4), (7), and (8) control the effect of industry, occupation, firm size, and age, respectively. When I control for the unobserved FE, the estimated impact of additional children on wages is approximately 2.3\% (see columns 5 and 7 ). ${ }^{13}$ Since the FE coefficients are larger than the ones obtained from OLS, a negative bias in the OLS estimators is likely. One interpretation is that the number of children and innate earning ability are negatively correlated. Japanese male workers who earn higher incomes tend to prefer having fewer children. However, since the difference between the OLS and FE estimators is not large, I believe that the correlation between the number of children and unobserved earning ability is not large.

The estimated results of nonlinear models indicate that having the second or the third child also increases wage at a $1 \%$ significant level. The additional impact of the birth of the second child is approximately $2.2 \%$ and that of the third child is in the range $2-1.8 \%$ when controlled for unobserved heterogeneity.

The finding that childbirth has significant impact on the wage of fathers is somewhat different from the result of Kawaguchi (2005a), who finds that only the birth of the third child has a significant impact on the wage of fathers. This disparity probably comes from a difference in sample periods, since I have similar results to Kawaguchi (2005a), if I only use the sample between 1991 and 2000. I divided the total sample into two cohorts - those born in or before 1960 and those born after 1960 - to examine whether the effects of children on wages differ among cohorts. As argued in Section 1, these cohorts seem to face entirely different labor market environments that may cause differences in the impact of childbirth among cohorts. Table 3 presents the estimated impact by cohort, which controls the effect of industry, occupation, firm size, and age, respectively. Columns (3) and (4) for FE estimations indicate a greater impact of childbirth on wage than the estimations of the full sample. The birth of children

13 Strictly speaking, the coefficients of dummy variables in the semi-log equation model do not indicate the percentage effect of these variables (Halvorsen and Palmquist 1980). However, the difference between the coefficient and percentage effects is rather small if the magnitude of the coefficient is small. Since our estimated impact on wage is small, I regard that the coefficient approximately captures percentage effects. 


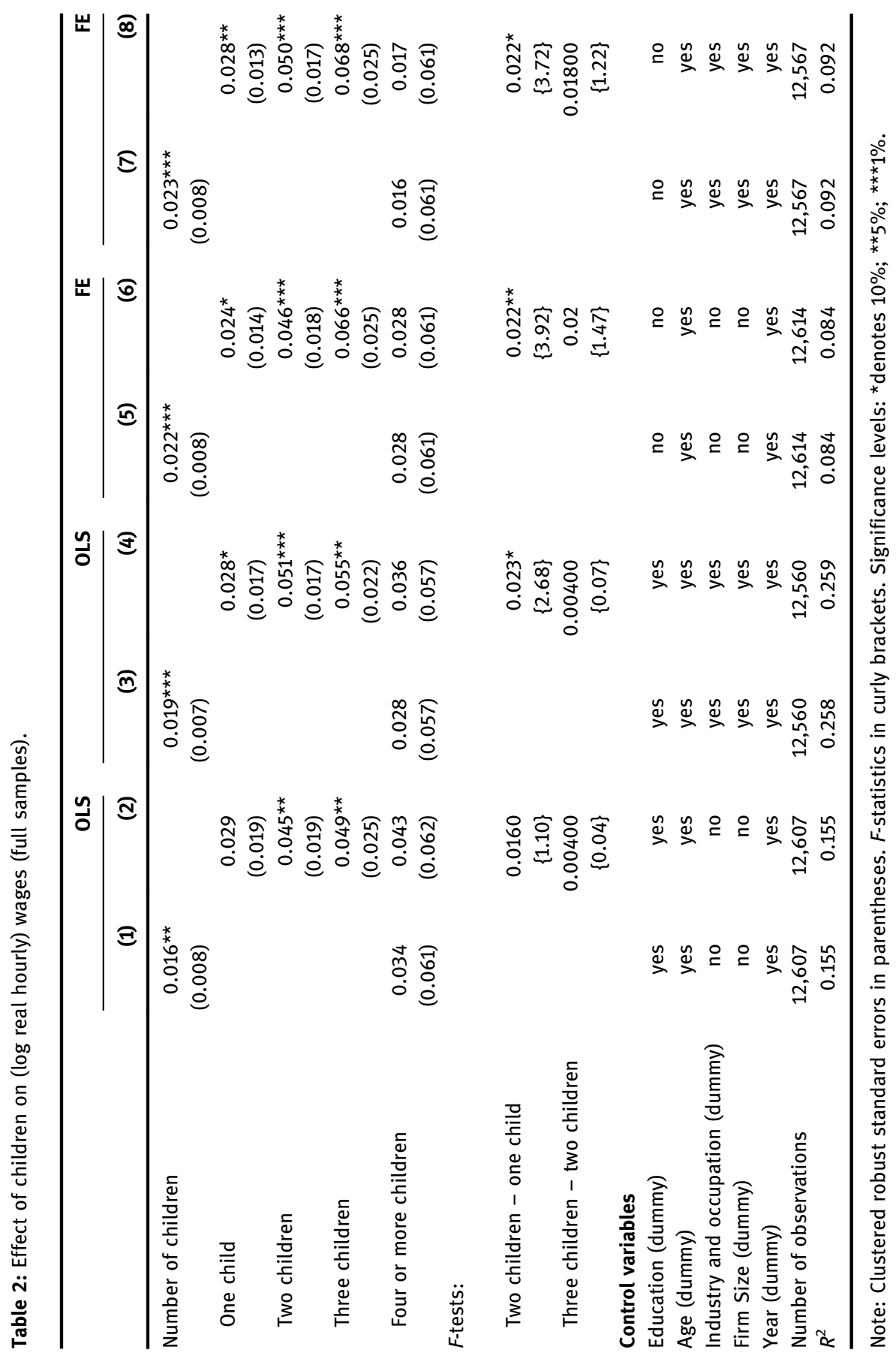


increases the wage rate of male workers by approximately $4 \%$ on average and is significant at the $10 \%$ level. Although the estimated impact in the early cohort is larger, the estimation results are less precise than those for the full sample, partly because of the decrease in sample size. Column (4) indicates that having the first and second children increases the fathers' wage by approximately $6.1 \%$, but these impacts are not statistically significant. The birth of the third child alone has a significant positive effect on wage. Since there is a large difference between the two estimators, the negative bias of the OLS estimator is larger in the early cohort. This may indicate a clear tendency for poor workers in the early cohort to have many children, which may cause the negative coefficient of the number of children in the OLS estimation.

Columns (5)-(8) in Table 3 present the estimated impact in the later cohort. When I control for unobserved heterogeneity, the estimated impact of childbirth on wage is less than $1 \%$ and not significant. In the later cohort, the OLS estimators predict a larger impact than the FE estimators. Therefore, in the later cohort, OLS estimators have a positive bias; this implies that poorer workers in the later cohort tend to have fewer children, which is contrary to the corresponding observation in the early cohort. ${ }^{14}$

From these results, I confirm that the birth of children has significantly positive effects on fathers' wage in Japan. The wage premium of fatherhood is $2.3 \%$ on average and nearly linear for the number of children. However, the estimated impacts differ among cohorts.

While the wage premium of fatherhood is substantial in the early cohort, a positive effect of childbirth on wage is not observed in the later cohort. These results indicate that the wage premium of fatherhood has in fact been decreasing in recent years. It would reflect that the long-term impact of childbirth is greater than the short-term impact, because a large part of an increase in wage is realized only after several years after childbirth by promotion later on in their careers. Otherwise, the recent trend in Japanese labor market would affect the work environment differently across cohorts. Sasajima (2009) points out a decrease in family benefits after the long-term stagnation during the 90s. If the younger workers have a lesser chance to get a job in a firm that provides generous family benefits than the elder workers, which is often argued, and arises due to labor market rigidity, the difference in impact of childbirth on wage comes from the difference in family benefits provided by the firm. I also find that biases of the OLS estimator due to unobservable characteristics are substantial and differ among

14 One interpretation on why the directions of bias of the OLS estimator are different across cohorts is that having children is expensive for the recent cohorts. This is consistent with the argument on the recent declining fertility rates in Japan (for example, see Morita 2006). 


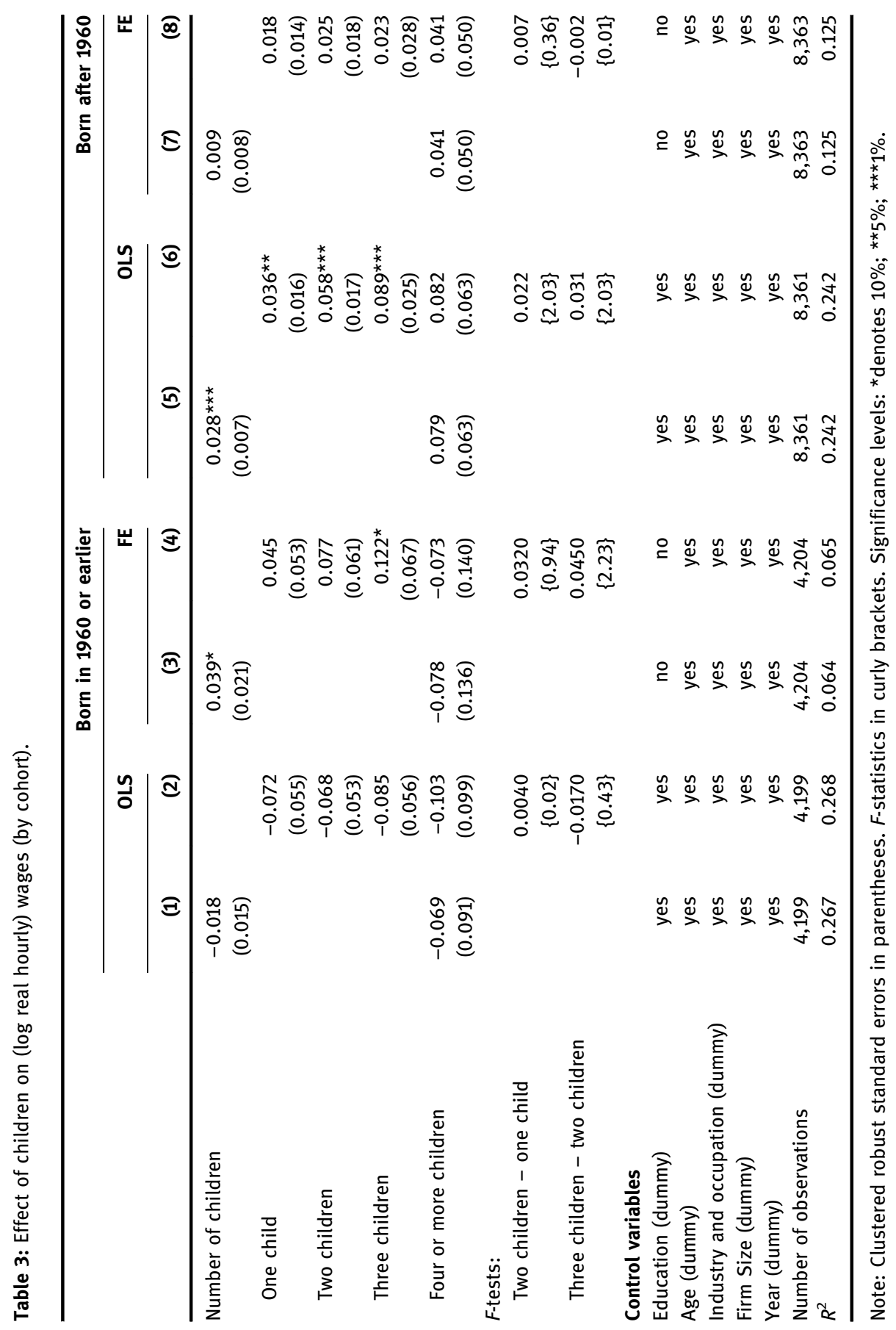


cohorts. In the early cohort, those who have more children are likely to earn lower wages, but in the later cohort, rich workers tend to have many children.

\subsection{The effects of children on labor supply}

Next, I examine how childbirth affects the labor supply of male workers. Table 4 presents the estimated impact on the labor supply in the total sample, where both estimators predict that childbirth increases the annual hours of work significantly. The estimated impact of childbirth on annual working hours is 69 hours on average, if I control for individual FE. The additional impact of the birth of the second child also increases the annual hours of work by 92-101 hours, a value that is not very different to the estimated impact of the birth of the first child (7377 hours). While the birth of a child generally increases the labor supply of fathers, the birth of the third child does not do so. Since the FE coefficients are larger than those of the OLS estimator, the latter may have a negative bias.

Table 5 presents the estimated impact of childbirth on the labor supply by cohort group. It is clear that the estimated impacts on the early cohort are very different between the OLS and FE estimators. The FE estimation in Columns (3), and (4) shows that the childbirth would have almost none or a negative effect on the annual hours of work. The observed large positive biases of OLS estimators imply that male workers who tend to work longer are likely to have many children. Considering this result with that of Table 3, I observe the tendency that workers in the early cohort who earn lower wages and work longer tend to have more children. The nonlinear model shows that the birth of the second child reduces working hours significantly. Columns (5)-(8) in Table 5 present the estimated effects on labor supply in the later cohort. Contrary to the results in the early cohort sample, the birth of children increases annual hours of work for men in both the OLS and FE models. The average impact of childbirth on annual work hours is 89 hours, if I control the effects of unobserved characteristics. OLS estimators would have a negative bias in the later cohort sample, which is contrary to their positive bias in the early cohort sample. In the later cohort, male workers who provide large amounts of labor supply are likely to have fewer children. The estimation of nonlinear models clarifies that the impact of childbirth is nonlinear, and that the impact of the birth of the third child is negative and not significant.

These results indicate that although childbirth significantly increases men's annual hours of work in Japan, its impact differs among cohorts. When unobserved heterogeneity is controlled, childbirth has no significant effect on the annual hours of work in the early cohort, but has a significantly positive impact on the later cohort. Therefore, contrary to the impact on wages, the effect of 


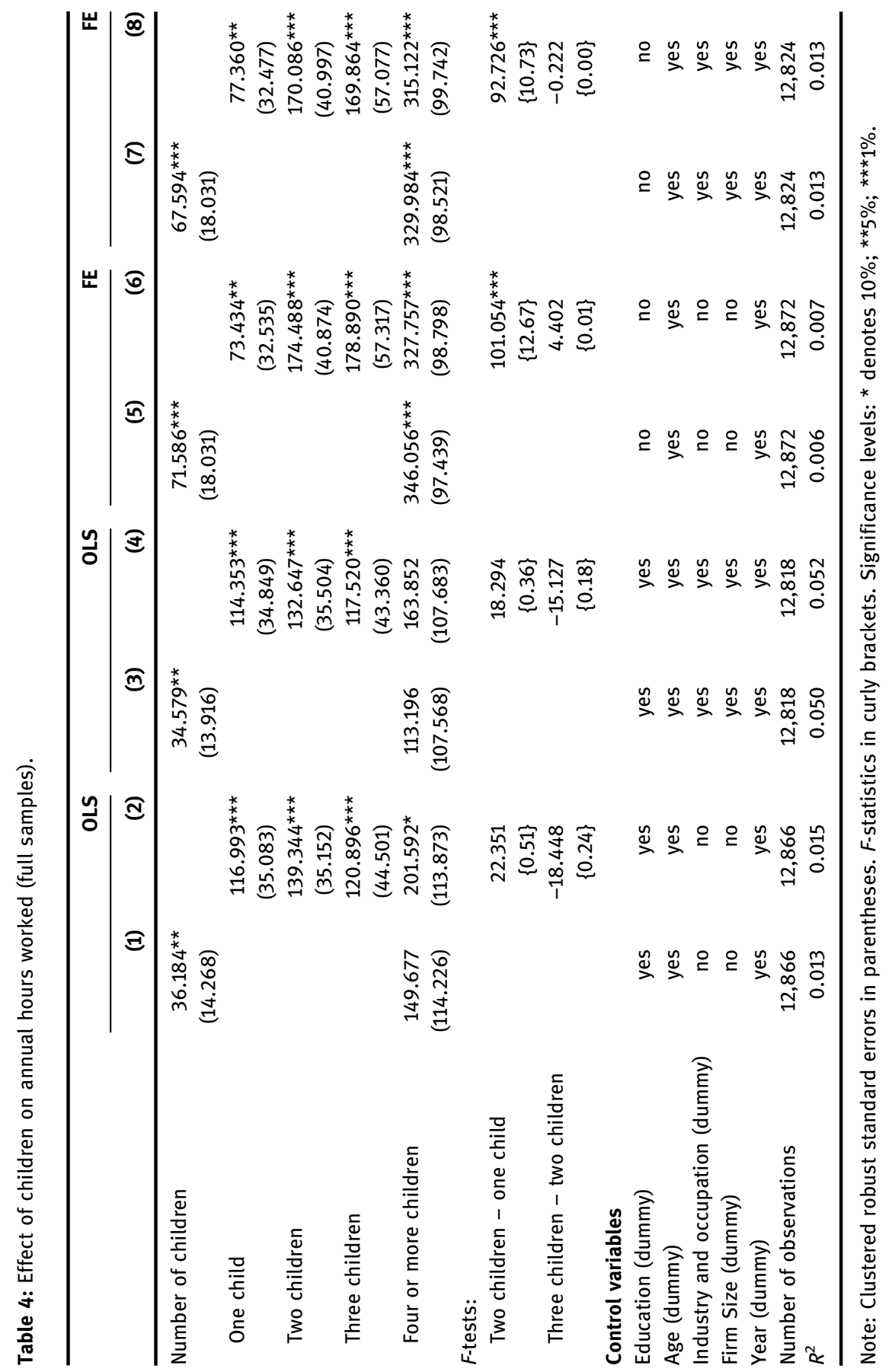




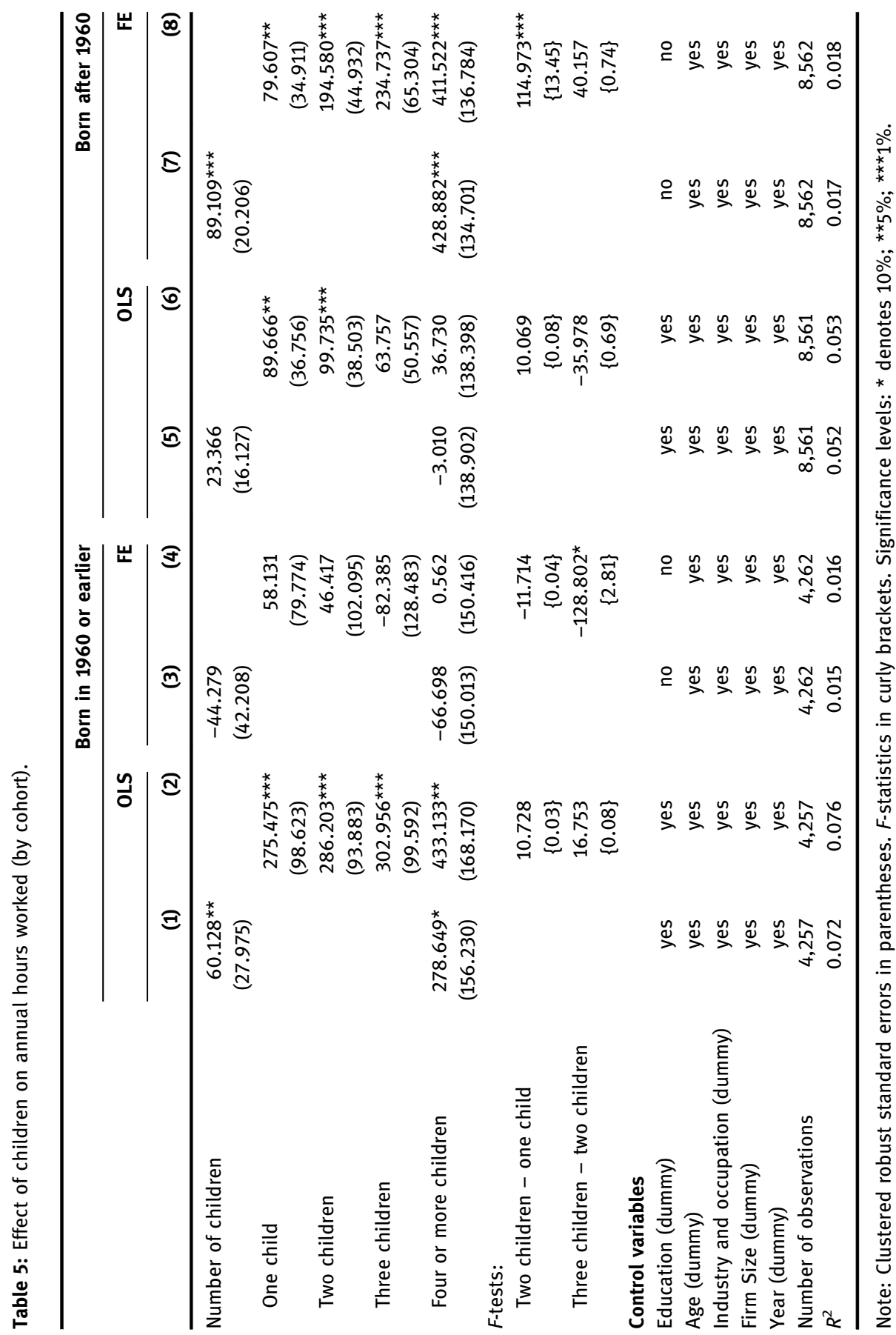


childbirth on the annual hours of work has been increasing in recent years. Moreover, the direction of bias of the OLS estimator differs between the two cohorts, which would suggest that the relation between unobserved ability or preference, and the fertility decision, has changed across cohorts. In the early cohort, those who work for a longer time, but earn low wages, are likely to have more children, but the opposite is true for the later cohort.

Now, I can summarize the impact of childbirth on labor market outcomes as follows. First, while the birth of children significantly increases the wage rates of male workers in the early cohort, it has no significant impact on their labor supply. Second, the birth of children increases the annual hours of work in the later cohort, but the wage premium of fatherhood cannot be observed in the later cohort. Third, in the early cohort, there is a strong tendency for those who earn lower wages and work longer hours to have more children. On the other hand, in the later cohort, workers who earn higher wages but work fewer hours tend to have more children. These results clearly show the effects of childbirth on both the wages, and the labor supply, and that the tendencies of behavior towards childbirth are very different between cohorts. Interestingly, the estimated increase in hours of work is about 3.3\% of average annual hours worked. ${ }^{15}$ This number is close to the estimated premium of childbirth on the wage rate in the early cohort. Hence, the estimated increase in the annual earnings due to childbirth is similar across cohorts. One interpretation is that male workers in the later cohort find that it is difficult to earn higher wages when they have a child, because they face tight labor market conditions, and so, they increase working hours in order to bear the costs of childcare.

\subsection{Discussion}

My empirical findings suggest that childbirth increases the wage rates of male workers by approximately $2.3 \%$, and annual working hours by approximately 69 hours in Japan; moreover, the impact of childbirth differs among cohorts. In this section, I briefly discuss the cause of these impacts. Since the intensity effect predicts a negative impact of childbirth on both the labor supply and wage, these results imply that the intensity effect is not strong in Japan. Then, can the observed positive impact of childbirth be interpreted as a result of the specialization effect? The specialization hypothesis predicts that childbirth positively affects the labor market outcomes of male workers, through sexual division of labor in the household.

15 The estimated impact of childbirth is about 85 hours in the later cohort. This number is about 3.3\% of the average hours worked for the cohort, which is about 2600 hours. 
In order to test the validity of the specialization hypothesis, I examine whether the estimated impact of childbirth changes, when I control for the effect of the wife's employment status. Lundberg and Rose (2000) showed that female work status affects male labor market outcomes. Here, I assume that the effects of the wives' work status on husbands' labor market outcomes capture the specialization effect, at least partially. If the positive impact of childbirth on the labor market outcome of husbands is caused largely by specialization in the household, which involves changes in the work status of wives, the estimated impact of childbirth becomes substantially small, if I control the variation in the work status of wives. I test this hypothesis in the following manner. However, note that the employment status of wives cannot capture the degree of specialization in the household, since specialization does not necessarily imply the exit of wives from the labor market. I can control for only a part of the specialization effect by including the employment status of wives in the empirical models.

I estimate the following extended linear model

$$
y_{i t}=\beta N_{i t}+\beta_{4} D_{i t}+\gamma X_{i t}+\delta W_{i t}+\alpha_{i}+u_{i t},
$$

where $W_{i t}$ indicates the wife's employment status in period $t$, which takes value of one if the wife works, and zero otherwise. Table 9 presents the results of childbirth effects on husbands' wages, when I control for the wives' employment status. It shows that the labor market participation of wives decreases the wage rate of husbands by approximately $1.7 \%$, which is consistent with the specialization hypothesis. The impact of childbirth decreases slightly to $2 \%$, but remains significantly positive even if I control for the wives' employment status. Table 10 presents the results of childbirth effects on the male labor supply when I control for the wives' employment status. It shows that the estimated impact of childbirth does not change, even if I control for this element. Therefore, the changes in the wives' employment status after childbirth does not seem to be an important source of estimated impact of childbirth. These results imply that the income effect, which predicts that childbirth increases labor supply or work effort because the value of income increases after childbirth, is the dominant factor that drives the premium of fatherhood. However, one cannot reject the specialization hypothesis with these results, since the wives' employment status is an incomplete measure of specialization. Wives would cause a decrease in the labor supply even if they do not quit their jobs, or if husbands would do less housework after childbirth. Without more information on household behavior, the importance of specialization within a household cannot be evaluated precisely.

It is also important to identify the source of the observed change in wage or hours of work after childbirth, especially whether the estimated impact of childbirth can be explained by the job turnover of fathers. If I can control the fixed 
effects of the firm, the importance of turnover could be estimated by comparing the baseline coefficient of number of children with those where I control the firm fixed effects. The difference between these two estimators captures the effect of childbirth when changing firms, that is, the impact of job turnover. However, I do not have data to identify the firm where the worker is currently employed. Therefore, I simply compare the baseline result with those where I restrict the sample to workers who did not change firms during the sample period. Table 11 shows that the estimated impact of childbirth on wages among these workers is not significant, and the impact on hours worked is less than the result in the full sample. Although this result seems to imply that childbirth affects labor market outcomes of their fathers mainly through the job turnover of fathers, I cannot accept the result at face value, since it does not rule out the selection bias problem. However, it could be said that the effect of turnover is not negligible in explaining the effect of childbirth on the labor market outcomes of their fathers. ${ }^{16}$

I also confirm whether changes in the type of jobs, that is, regular employment or non-regular employment, is important for changes in the labor market outcomes of fathers after childbirth. As shown in Table 12, the estimated impact does not change even if I control for the type of employment. Therefore, the change in type of employment contract would not alter the impact of childbirth on the labor market outcomes of their fathers.

Table 13 shows the result when I control for savings and the value of the portfolio, which are proxies for wealth of the household, to examine whether the income effect explains the increase in hours of work due to childbirth. The table shows that the estimated impact does not change if I include these variables as control variables. Therefore, the income effect would not play a major part in the relationship between hours of work and childbirth.

Finally, I investigate the possibility that the estimated impact of childbirth on wages captures the effect of family allowance pay only. Although there is only limited information on family allowance, I believe that the family allowance pay does not explain the entire impact. According to the survey on wages (chingin-zijoutou sougou chousa) conducted by the Ministry of Health, Labor and Welfare, approximately $80 \%$ of large firms - which have over 1,000 employees pay family allowance to workers. The average amount of child allowance provided by these firms is approximately 7,000 yen, which is roughly equal to $2 \%$ of

16 In fact, job turnover rate in the few years after child birth is higher than the average in our JPSC sample. For example, $6.0 \%$ of workers changes jobs at the period when they have new children, which is significantly higher than the fraction of workers who change jobs for overall JPSC sample (4.6\%). The probit estimation also shows that childbirth significantly increases the probability of job turnover. These results are available upon request. 
the average monthly wages in our sample. On the other hand, the survey on wage and retirement allowance of small firms in the Tokyo metropolitan area (chushou-kigyou no tingin taishokukin zijou), conducted by the Tokyo Metropolitan Government Bureau of Industrial and Labor Affairs, shows that only 65\% of small firms (with less than 300 employees) pay family allowance, and the average amount of child benefit is approximately 5,000 yen. Since the estimated impact of childbirth in this study captures the average effect of all samples, and about $40 \%$ of our sample is employed by companies that have less than 100 employees, family allowance pay can explain only a part of the estimated impact of childbirth on wage. ${ }^{17}$ Moreover, the family allowance pay effect does not explain why the impact of childbirth on wage differs across cohorts.

I now compare my results with those of Lundberg and Rose (2002) and Choi et al. (2008) to ascertain differences and similarities in the impact of childbirth on male wages and their annual work hours among Japan, the US, and Germany. Figure 3(a) shows that the impact of childbirth on wages is larger in the US and Germany than in Japan. Figure 3(b) shows that the impact of childbirth on labor supply is larger in Japan than in the US and Germany, except for the birth of the first child in the US. Can these differences in the impact of childbirth among Japan, the US, and Germany be interpreted as being caused by differences in labor market institutions and customs? Burgess (1999) showed that the proportion of employed males in the age group of 26-45 years in temporary jobs (1 year or less), was $20 \%$ in the US, $16.34 \%$ in Germany, and $4.32 \%$ in Japan. Further, Sousa-Poza and Henneberger (2004) showed that the turnover intention rates in the US and Germany are larger than that in Japan. Since the labor market in the US and Germany is more flexible compared to Japan, workers in these countries may be able to change jobs when they have children. On the other hand, the relationship between wages and performance is relatively weak in Japan, which may account for the differences in the impact of childbirth on wages among the US, Japan, and Germany. However, since the impact of childbirth on wages in the early cohort in this study is almost the same as that in the US, the gap in the wage premium of fatherhood among the three countries may be caused by the long-term economic stagnation during, and after the 1990s in Japan; thus, it cannot be explained conclusively by institutional factors.

In order to ascertain the robustness of my findings from the cohort analysis, I test whether my results change if the sample is segmented differently. I divide the total sample into three cohorts (born in 1960 or earlier, born between 1961 and 1965, and those born after 1965) and examine whether the effects of childbirth on

17 In our sample, the share of workers employed by large firms - that have over 1,000 employees - is approximately $20 \%$. 
(a)

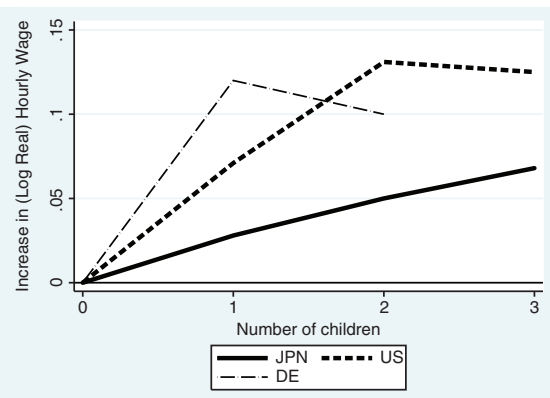

(b)

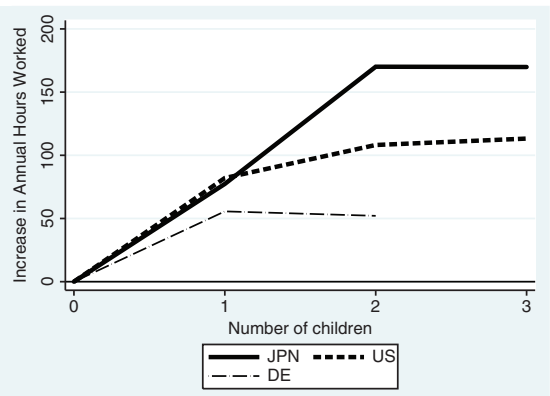

Figure 3: Effect of children on (log real hourly) wage and annual hours of work: A comparison among Japan, Germany, and the U.S. (a) Log real hourly wage. (b) Annual hours of work. Note: Data pertaining to the US and Germany are sourced from Lundberg and Rose (2002) and Choi et al. (2008), respectively.

male wage and labor supply show a similar trend to the one seen in earlier sections. Table 14 shows the effect of childbirth on male wages and labor supply for the three cohorts. Childbirth is significant at the $5 \%$ level and has positive effects on male wages for the earliest cohort alone (born in 1960 or earlier). For this cohort, childbirth leads to an increase in male wages by approximately $3.9 \%$. In the second cohort (born between 1961 and 1965), childbirth still has a positive but smaller effect on wages of males. Further, in the latest cohort, childbirth is not significant and has a negative effect on male wages. These results indicate that the wage premium has been decreasing in recent years, and this trend is observed in the results of two cohorts (born in 1960 or earlier and born after 1960). On the contrary, childbirth is significant for the latest cohort and has a positive effect on the labor supply. Childbirth increases annual work hours by approximately 108 hours in the latest cohort. In the cohort born between 1961 and 1965, childbirth also has a positive effect on the labor supply, but the estimated impact of childbirth on labor supply is small. Moreover, childbirth has a negative and insignificant effect on the labor supply in the earliest cohort. These findings are consistent with my main results. Therefore, it can be stated that the above findings do not depend on the definition of cohort groups.

\subsection{The effects of child gender on wage and labor supply}

Finally, I examine whether differences in the gender of the child affect the impact of childbirth on labor market outcomes. Table 6 presents the effects of 
child gender on wages. It shows all results that correspond to specifications (i)-(iv). Table 6 shows that, irrespective of model specifications, the impact on wages is not significantly larger for either gender. Child gender has no significant effects on men's wages in either the full sample or both the cohort samples. These results have also been observed in the US; Lundberg and Rose (2002) showed that difference in child gender had no significant effect on men's wages.

Table 7 shows the results pertaining to the effects of child gender on the male labor supply. The effect of number of sons is larger than that exerted by the number of daughters, but the difference is not statistically significant. This result does not change even if we divide the sample into the early cohort and the later cohort. Therefore, children have no significant effect on men's annual hours of work in the early cohort sample, based on the gender of the child.

According to these results, child gender does not seem to have any significant effects on men's labor market outcomes in Japan. This result is contrary to that of Lundberg and Rose (2002) for the US, which showed that the birth of sons has a significantly larger impact than the birth of daughters. This finding might seem somewhat surprising, because a strong preference for sons is observed in many Asian countries (e.g. Das 1984; Arnold and Liu 1986; Larsen et al. 1998). However, Kureishi and Wakabayashi (2011) find that son preference is not observed among the cohort born after 1940 in Japan. One possible explanation of this is that the generous social security system makes economic ties between elderly parents and their adult children weak, although cultural ties are strong, as in other Asian countries. ${ }^{18}$ The difference in the generosity of social security may be able to explain the difference in the gender effect between Japan and the US, if the gender effect of childbirth comes from old-age support motive of parents, which is one possible explanation of the gender effect, Lundberg and Rose (2002) provide. If sons are less likely to take care of their parents than daughters, fathers who have sons would work harder than those who have daughters to provide for them in their old age. In Japan, parents would have less old-age support motive than those in the US because social security guarantees the living expenses of parents in their old age.

\section{Conclusion}

Using data from the JPSC for the period 1994-2007, I examined the effect of childbirth on male wage rates and the male labor supply in Japan. I also

18 As Das Gupta et al. (2003) and Chung and Das Gupta (2007) point out, the economic independence of the elderly is negatively related with son preference. 
Table 6: Effect of sons or daughters on (log real hourly) wages.

\begin{tabular}{|c|c|c|c|c|}
\hline $\begin{array}{l}\text { Specification } \\
\text { number }\end{array}$ & & Full sample & $\begin{array}{r}\text { Born in } 1960 \text { or } \\
\text { earlier }\end{array}$ & $\begin{array}{r}\text { Born after } \\
1960\end{array}$ \\
\hline \multirow[t]{6}{*}{ (i) } & Number of boys & $0.023^{\star \star}$ & 0.043 & 0.010 \\
\hline & (0 if none or $>2$ ) & $(0.011)$ & $(0.027)$ & $(0.012)$ \\
\hline & Number of girls & $0.023^{\star \star}$ & 0.033 & 0.010 \\
\hline & (0 if none or $>2$ ) & $(0.010)$ & $(0.027)$ & $(0.011)$ \\
\hline & Three or more boys or three or & 0.033 & 0.041 & 0.001 \\
\hline & more girls & $(0.034)$ & $(0.080)$ & $(0.037)$ \\
\hline \multirow[t]{2}{*}{ F-tests: } & Number of boys - Number of & 0.0003 & 0.01 & 0.0007 \\
\hline & girls & $\{0.00\}$ & $\{0.09\}$ & $\{0.00\}$ \\
\hline \multirow[t]{4}{*}{ (ii) } & At least one boy & $0.023^{\star}$ & 0.043 & 0.012 \\
\hline & & $(0.013)$ & $(0.043)$ & $(0.014)$ \\
\hline & At least one girl & $0.031^{\star \star}$ & 0.052 & 0.017 \\
\hline & & $(0.013)$ & $(0.033)$ & $(0.014)$ \\
\hline \multirow[t]{2}{*}{ F-tests: } & At least one boy - At least one & -0.008 & -0.009 & -0.005 \\
\hline & girl & $\{0.20\}$ & $\{0.03\}$ & $\{0.06\}$ \\
\hline \multirow[t]{4}{*}{ (iii) } & If first child is a boy & 0.026 & 0.153 & 0.012 \\
\hline & & $(0.018)$ & $(0.113)$ & $(0.019)$ \\
\hline & If first child is a girl & $0.038^{\star}$ & 0.012 & 0.028 \\
\hline & & $(0.019)$ & $(0.053)$ & $(0.020)$ \\
\hline \multirow[t]{2}{*}{ F-tests: } & If first child is a boy - If first & -0.012 & 0.141 & -0.016 \\
\hline & child is a girl & $\{0.23\}$ & $\{1.31\}$ & $\{0.36\}$ \\
\hline \multirow[t]{4}{*}{ (iv) } & One boy & $0.022^{\star}$ & 0.015 & 0.013 \\
\hline & & $(0.013)$ & $(0.040)$ & $(0.015)$ \\
\hline & One girl & $0.035^{\star \star \star}$ & $0.063^{\star *}$ & 0.019 \\
\hline & & $(0.012)$ & $(0.031)$ & $(0.013)$ \\
\hline \multirow[t]{6}{*}{ F-tests: } & One boy - One girl & -0.013 & -0.048 & -0.006 \\
\hline & & $\{0.54\}$ & $\{0.92\}$ & $\{0.09\}$ \\
\hline & Two boys & $0.045^{\star \star}$ & 0.072 & 0.017 \\
\hline & & $(0.022)$ & $(0.054)$ & $(0.025)$ \\
\hline & Two girls & $0.036^{\star}$ & 0.057 & 0.010 \\
\hline & & $(0.021)$ & $(0.055)$ & $(0.022)$ \\
\hline \multirow[t]{4}{*}{$F$-tests: } & Two boys - Two girls & 0.009 & 0.015 & 0.007 \\
\hline & & $\{0.10\}$ & $\{0.04\}$ & $\{0.07\}$ \\
\hline & More than two boys or two girls & 0.030 & 0.030 & -0.002 \\
\hline & & $(0.035)$ & $(0.082)$ & $(0.038)$ \\
\hline
\end{tabular}

Note: Clustered robust standard errors in parentheses. F-statistics in curly brackets. Significance levels: * denotes $10 \% ;{ }^{\star \star} 5 \%$; ${ }^{\star \star \star} 1 \%$. All equations control for education (in case of OLS), age, industry, occupation, firm size, and year. 
Table 7: Effect of sons or daughters on annual hours worked.

\begin{tabular}{|c|c|c|c|c|}
\hline $\begin{array}{l}\text { Specification } \\
\text { number }\end{array}$ & & Full sample & $\begin{array}{r}\text { Born in } 1960 \text { or } \\
\text { earlier }\end{array}$ & $\begin{array}{r}\text { Born after } \\
1960\end{array}$ \\
\hline \multirow[t]{5}{*}{ (i) } & Number of boys & $103.765^{\star \star \star}$ & 3.747 & $120.562^{\star \star \star}$ \\
\hline & (0 if none or $>2$ ) & $(25.684)$ & $(52.898)$ & $(28.937)$ \\
\hline & Number of girls & $48.825^{\star \star}$ & -82.986 & $75.537^{\star \star \star}$ \\
\hline & (0 if none or $>2$ ) & $(24.025)$ & $(55.257)$ & $(26.694)$ \\
\hline & $\begin{array}{l}\text { Three or more boys or three or } \\
\text { more girls }\end{array}$ & $\begin{array}{l}159.959^{\star \star} \\
(66.684)\end{array}$ & $\begin{array}{l}-129.769 \\
(143.759)\end{array}$ & $\begin{array}{l}210.652^{\star \star \star} \\
(75.604)\end{array}$ \\
\hline F-tests: & $\begin{array}{l}\text { Number of boys - Number of } \\
\text { girls }\end{array}$ & $\begin{array}{l}54.94^{\star} \\
\{2.78\}\end{array}$ & $\begin{array}{r}86.733 \\
\{1.60\}\end{array}$ & $\begin{array}{r}45.025 \\
\{1.50\}\end{array}$ \\
\hline \multirow[t]{2}{*}{ (ii) } & At least one boy & $\begin{array}{l}92.385^{\star \star} \\
(38.202)\end{array}$ & $\begin{array}{r}41.483 \\
(79.567)\end{array}$ & $\begin{array}{l}95.566^{\star \star} \\
(41.101)\end{array}$ \\
\hline & At least one girl & $\begin{array}{l}68.195^{\star *} \\
(32.258)\end{array}$ & $\begin{array}{r}8.864 \\
(69.808)\end{array}$ & $\begin{array}{l}77.555^{\star \star} \\
(35.395)\end{array}$ \\
\hline F-tests: & $\begin{array}{l}\text { At least one boy - At least one } \\
\text { girl }\end{array}$ & $\begin{array}{r}24.19 \\
\{0.22\}\end{array}$ & $\begin{array}{r}32.619 \\
\{0.10\}\end{array}$ & $\begin{array}{r}18.011 \\
\{0.10\}\end{array}$ \\
\hline \multirow[t]{2}{*}{ (iii) } & If first child is a boy & $\begin{array}{l}109.974^{\star \star} \\
(45.962)\end{array}$ & $\begin{array}{r}188.245 \\
(160.886)\end{array}$ & $\begin{array}{l}100.707^{\star \star} \\
(47.982)\end{array}$ \\
\hline & If first child is a girl & $\begin{array}{r}73.177 \\
(44.787)\end{array}$ & $\begin{array}{l}-29.319 \\
(80.992)\end{array}$ & $\begin{array}{r}78.280 \\
(49.329)\end{array}$ \\
\hline F-tests: & $\begin{array}{l}\text { If first child is a boy - If first } \\
\text { child is a girl }\end{array}$ & $\begin{array}{r}36.797 \\
\{0.34\}\end{array}$ & $\begin{array}{r}217.564 \\
\{1.49\}\end{array}$ & $\begin{array}{r}22.427 \\
\{0.11\}\end{array}$ \\
\hline \multirow[t]{2}{*}{ (iv) } & One boy & $\begin{array}{l}100.613^{\star \star *} \\
(36.301)\end{array}$ & $\begin{array}{r}87.782 \\
(81.957)\end{array}$ & $\begin{array}{l}101.081^{\star \star \star} \\
(39.058)\end{array}$ \\
\hline & One girl & $\begin{array}{l}58.419^{\star} \\
(31.313)\end{array}$ & $\begin{array}{l}-18.187 \\
(67.897)\end{array}$ & $\begin{array}{l}75.362^{\star \star} \\
(34.379)\end{array}$ \\
\hline \multirow[t]{3}{*}{ F-tests: } & One boy - One girl & $\begin{array}{r}42.194 \\
\{0.77\}\end{array}$ & $\begin{array}{r}105.969 \\
\{1.13\}\end{array}$ & $\begin{array}{l}25.719 \\
\{0.24\}\end{array}$ \\
\hline & Two boys & $\begin{array}{l}207.026^{* \star *} \\
(51.732)\end{array}$ & $\begin{array}{r}34.627 \\
(102.452)\end{array}$ & $\begin{array}{l}253.670^{\star \star \star} \\
(58.800)\end{array}$ \\
\hline & Two girls & $\begin{array}{l}90.212^{*} \\
(50.526)\end{array}$ & $\begin{array}{l}-167.979 \\
(112.895)\end{array}$ & $\begin{array}{l}157.770^{\star \star \star \star} \\
(56.070)\end{array}$ \\
\hline \multirow[t]{2}{*}{ F-tests: } & Two boys - Two girls & $\begin{array}{c}116.814^{\star} \\
\{3.02\}\end{array}$ & $\begin{array}{r}202.606 \\
\{2.43\}\end{array}$ & $\begin{array}{r}95.9 \\
\{1.64\}\end{array}$ \\
\hline & More than two boys or two girls & $\begin{array}{l}158.519 \star \star \\
(67.012)\end{array}$ & $\begin{array}{l}-106.213 \\
(140.761)\end{array}$ & $\begin{array}{l}217.473^{\star \star \star} \\
(76.034)\end{array}$ \\
\hline
\end{tabular}

Note: Clustered robust standard errors in parentheses. F-statistics in curly brackets. Significance levels: ${ }^{\star}$ denotes $10 \% ;{ }^{*} 5 \% ;{ }^{\star \star \star} 1 \%$. All equations control for education (in case of OLS), age, industry, occupation, firm size, and year. 
compared the effects of fatherhood among different cohorts by dividing the JPSC sample into two cohorts by birth year (born in or before 1960 and born after 1960).

I found that the birth of children significantly increased hourly wage rates by $2.3 \%$ and the annual working hours by 69 hours. Compared to the results from the US (Lundberg and Rose 2002) and German (Choi et al. 2008) studies, the effect of childbirth on the male labor supply in Japan was found to be large, but its effect on wage rates was relatively small. I also found that childbirth had a different impact on labor market outcomes between the early and later cohorts. In the former, childbirth significantly increased wage rates, but did not significantly affect the labor supply. On the contrary, in the later cohort, while childbirth did not lead to an increase in wage rates, it did significantly increase the labor supply. Finally, I also examined the role of child gender on male labor market outcomes. Although the impact of child gender was not large, the effect of the birth of sons was larger than that of the birth of daughters. Moreover, the effects of child gender also differed between cohorts for certain specifications.

The question of why the impact of childbirth differs across cohorts should be addressed in further research. One interpretation is that the wives in the recent cohorts tend to have a more individualistic view on sexual division of labor; thus, households in recent cohorts do not gain from intra-household division of labor. Another interpretation is that long-term stagnation in Japan has decreased the quality of jobs for young cohorts, which is consistent with the fact that the share of non-regular workers among young workers has increased during previous decades. In these jobs, an increase in the productivity of workers would only be weakly related to wages. Moreover, the direction of bias in the OLS estimation indicates that the pattern of fertility choice differs across cohorts. Therefore, it is important to know how fertility decisions are affected by household income, and whether they differ across cohorts, for understanding the cause of change in the premium of fatherhood. This research would also be important for evaluating the effectiveness of public child allowance policies.

Acknowledgments: I am deeply grateful to Hisakazu Matsushige and Ayako Kondo for many valuable advices and suggestions. A special thanks to Ryosuke Okazawa for his details comments. I also thank to Hideo Akabayashi, Ryosuke Ishii, Ryotaro Fukahori, Risa Hagiwara, Fang HE, Yoshio Higuchi, Keiichiro Honda, Wataru Kureishi, Kayo Nozaki, Souichi Ohta, Tsunehiro Otsuki, Kazuyasu Sakamoto, Kazuma Sato, Miki Seko, Atsuko Ueda, Midori Wakabayashi, Isamu Yamamoto, Shoko Yamane, Haruka Yane, two anonymous referees, and the participants of the Japanese Economic Association Meeting at 
Kumamoto Gakuen University and Summer Workshop of Economic Theory at Otaru University of Commerce for helpful comments. Also, I thank the Institute for Research on Household Economics for providing data collected by the Japanese Panel Survey of Consumers (JPSC). This work was supported by Grant-in-Aid for the Japanese Society for the Promotion of Science (JSPS) Fellows. All remaining errors are my own.

\section{Appendix}

Following Kondo (2008), the calculation procedure of the number of hours and the real hourly wage

Since JPSC does not directly ask respondents about the number of hours worked annually, I calculate this element from the data on weekday hours of work and annual days of work. The JPSC poses two types of questions concerning hours of work for males. The first question concerns the man's real work hours for one weekday and one holiday. The other deals with the categorical variable of their weekly hours of work. As the former question is more detailed, I use it to calculate annual work hours. Annual days of work is a categorical variable that may be classified as follows: (1) less than 50 days, (2) 50-99 days, (3) 100-149 days, (4) 150-174 days, (5) 175-199 days, (6) 200-224 days, (7) 225-249 days, (8) 250-274 days, (9) 275-299 days, and (10) more than 300 days. I replace "less than 50 days" with "30 days," "more than 300 days" with "320 days," and the other categories with corresponding intermediate values. I thus calculate annual work hours as the product of hours of work in one weekday and annual days of work. The result of the paper does not depend on the choice of the measure of labor supply. We have similar results when we use hourly work hours.

I also calculate the real hourly wage by the following procedure; the respondents report their labor earnings according to their salary payment type. When the respondent reports his hourly wage, I use this value as the hourly wage. If the respondent reports his daily wage, I divide the daily wage by average daily hours of works and use the resulting value as the hourly wage. If the respondent was asked about the monthly wage, I divide the monthly wage by the weekly working hours multiplied by 4.3 (i.e. the average number of weeks in a month considering a 52-week year), and use the resulting value as the hourly wage. Finally, I deflate the hourly wage by the consumer price index. 
Table 8: Summary statistics.

\begin{tabular}{|c|c|c|c|}
\hline & Full sample & Born in 1960 or earlier & Born after 1960 \\
\hline \multicolumn{4}{|l|}{ Firm Size $\mathrm{a}^{\mathrm{a}}$} \\
\hline \multirow[t]{2}{*}{ Small (less than 100) } & 0.397 & 0.404 & 0.393 \\
\hline & $(0.489)$ & $(0.491)$ & $(0.489)$ \\
\hline \multirow[t]{2}{*}{ Medium (100 to 999) } & 0.289 & 0.282 & 0.293 \\
\hline & $(0.453)$ & $(0.450)$ & $(0.455)$ \\
\hline \multirow[t]{2}{*}{$\mathrm{Big}$ (more than 1,000 ) } & 0.200 & 0.186 & 0.207 \\
\hline & $(0.400)$ & $(0.389)$ & $(0.405)$ \\
\hline \multirow[t]{2}{*}{ Public office } & 0.113 & 0.128 & 0.106 \\
\hline & $(0.317)$ & $(0.334)$ & $(0.308)$ \\
\hline \multicolumn{4}{|l|}{ Industry ${ }^{a}$} \\
\hline \multirow[t]{2}{*}{ Agriculture, forestry, fishery, or mining } & 0.008 & 0.012 & 0.007 \\
\hline & $(0.093)$ & $(0.108)$ & $(0.085)$ \\
\hline \multirow[t]{2}{*}{ Construction } & 0.137 & 0.138 & 0.137 \\
\hline & $(0.344)$ & $(0.345)$ & $(0.344)$ \\
\hline \multirow[t]{2}{*}{ Manufacturing } & 0.272 & 0.259 & 0.280 \\
\hline & $(0.445)$ & $(0.438)$ & $(0.449)$ \\
\hline \multirow[t]{2}{*}{ Wholesale, retail } & 0.152 & 0.176 & 0.141 \\
\hline & $(0.359)$ & $(0.381)$ & $(0.348)$ \\
\hline \multirow[t]{2}{*}{ Finance, insurance or real estate } & 0.0605 & 0.056 & 0.063 \\
\hline & $(0.238)$ & $(0.230)$ & $(0.243)$ \\
\hline \multirow{2}{*}{$\begin{array}{l}\text { Transportation, communication, electricity, gas, } \\
\text { water utility, or heat supply }\end{array}$} & 0.115 & 0.105 & 0.121 \\
\hline & $(0.319)$ & $(0.306)$ & $(0.326)$ \\
\hline \multirow[t]{2}{*}{ Service or other } & 0.142 & 0.129 & 0.149 \\
\hline & $(0.349)$ & $(0.335)$ & $(0.356)$ \\
\hline \multirow[t]{2}{*}{ Public service } & 0.110 & 0.126 & 0.103 \\
\hline & $(0.313)$ & $(0.332)$ & $(0.304)$ \\
\hline \multicolumn{4}{|l|}{ Occupation dummy ${ }^{a}$} \\
\hline \multirow[t]{2}{*}{ Manager } & 0.0559 & 0.084 & 0.042 \\
\hline & $(0.229)$ & $(0.277)$ & $(0.200)$ \\
\hline \multirow[t]{2}{*}{ Expert, engineer, or teacher } & 0.207 & 0.215 & 0.205 \\
\hline & $(0.405)$ & $(0.411)$ & $(0.403)$ \\
\hline \multirow[t]{2}{*}{ Clerical worker } & 0.269 & 0.264 & 0.273 \\
\hline & $(0.443)$ & $(0.441)$ & $(0.446)$ \\
\hline \multirow[t]{2}{*}{ Technical worker } & 0.362 & 0.328 & 0.379 \\
\hline & $(0.480)$ & $(0.470)$ & $(0.485)$ \\
\hline \multirow[t]{2}{*}{ Service worker } & 0.104 & 0.109 & 0.102 \\
\hline & $(0.305)$ & $(0.312)$ & $(0.302)$ \\
\hline \multirow[t]{2}{*}{ Log of savings ${ }^{b}$} & 4.575 & 4.843 & 4.443 \\
\hline & $(2.28)$ & (2.353) & $(2.229)$ \\
\hline \multirow[t]{2}{*}{ Log of portfolio ${ }^{b}$} & 0.602 & 0.811 & 0.499 \\
\hline & $(1.685)$ & $(1.947)$ & $(1.528)$ \\
\hline \multirow[t]{2}{*}{ Regular employment $^{\mathrm{c}}$} & 0.978 & 0.977 & 0.978 \\
\hline & $(0.148)$ & $(0.149)$ & $(0.147)$ \\
\hline Number of observations & 12,872 & 4,271 & 8,601 \\
\hline
\end{tabular}

a Based on 12,824 observations (4,262 for the first cohort, and 8,562, for the second). ${ }^{\mathrm{b}}$ Based on 11,895 observations (3,938 for the first cohort, and 7,957, for the second). ${ }^{c}$ Based on 12,816 observations ( 4,260 for the first cohort, and 8,556 , for the second). 
Table 9: Effect of children on wages when controlling for the employment status of wives.

\begin{tabular}{|c|c|c|c|c|c|c|}
\hline \multirow[b]{2}{*}{ Number of children } & \multicolumn{2}{|r|}{ Full sample } & \multicolumn{2}{|c|}{ Born in 1960 or earlier } & \multicolumn{2}{|c|}{ Born after 1960} \\
\hline & $\begin{array}{l}0.023^{\star \star \star *} \\
(0.008)\end{array}$ & $\begin{array}{l}0.020^{\star \star \star} \\
(0.008)\end{array}$ & $\begin{array}{c}0.039^{\star} \\
(0.021)\end{array}$ & $\begin{array}{c}0.038^{\star} \\
(0.021)\end{array}$ & $\begin{array}{r}0.009 \\
(0.008)\end{array}$ & $\begin{array}{r}0.005 \\
(0.008)\end{array}$ \\
\hline Four or more children & $\begin{array}{r}0.016 \\
(0.061)\end{array}$ & $\begin{array}{r}0.006 \\
(0.062)\end{array}$ & $\begin{array}{l}-0.078 \\
(0.136)\end{array}$ & $\begin{array}{r}-0.080 \\
(0.136)\end{array}$ & $\begin{array}{r}0.041 \\
(0.050)\end{array}$ & $\begin{array}{r}0.023 \\
(0.050)\end{array}$ \\
\hline Wife's employment status & & $\begin{array}{l}-0.017^{\star \star} \\
(0.008)\end{array}$ & & $\begin{array}{l}-0.017 \\
(0.016)\end{array}$ & & $\begin{array}{l}-0.022^{\star \star} \\
(0.009)\end{array}$ \\
\hline Control variables & & & & & & \\
\hline Education (dummy) & no & no & no & no & no & no \\
\hline Age (dummy) & yes & yes & yes & yes & yes & yes \\
\hline $\begin{array}{l}\text { Industry and Occupation } \\
\text { (dummy) }\end{array}$ & yes & yes & yes & yes & yes & yes \\
\hline Firm Size (dummy) & yes & yes & yes & yes & yes & yes \\
\hline Year (dummy) & yes & yes & yes & yes & yes & yes \\
\hline Observations & 12,567 & 12,567 & 4,204 & 4,204 & 8,363 & 8,363 \\
\hline$R^{2}$ & 0.092 & 0.092 & 0.064 & 0.065 & 0.125 & 0.126 \\
\hline
\end{tabular}

Note: Clustered robust standard errors in parentheses. Significance levels: * denotes $10 \%$; $\star \star 5 \%$; $* \star * 1 \%$.

Table 10: Effect of children on annual hours when controlling for the employment status of wives.

\begin{tabular}{|c|c|c|c|c|c|c|}
\hline \multirow[b]{2}{*}{ Number of children } & \multirow[b]{2}{*}{$\begin{array}{l}67.594^{\star \star \star} \\
(18.031)\end{array}$} & \multirow{2}{*}{$\begin{array}{c}\text { Full sample } \\
61.888^{\star \star \star} \\
(18.102)\end{array}$} & \multicolumn{2}{|c|}{ Born in 1960 or earlier } & \multicolumn{2}{|c|}{ Born after 1960} \\
\hline & & & $\begin{array}{l}-44.279 \\
(42.208)\end{array}$ & $\begin{array}{l}-46.609 \\
(42.026)\end{array}$ & $\begin{array}{l}89.109 * \star \star \\
(20.206)\end{array}$ & $\begin{array}{l}83.704^{\star \star \star} \\
(19.990)\end{array}$ \\
\hline Four or more children & $\begin{array}{l}329.984^{\star \star \star *} \\
(98.521)\end{array}$ & $\begin{array}{l}304.874^{\star \star \star} \\
(98.647)\end{array}$ & $\begin{array}{l}-66.698 \\
(150.013)\end{array}$ & $\begin{array}{l}-76.839 \\
(151.270)\end{array}$ & $\begin{array}{l}428.882^{\star \star \star} \\
(134.701)\end{array}$ & $\begin{array}{l}403.300^{\star \star \star *} \\
(133.674)\end{array}$ \\
\hline $\begin{array}{l}\text { Wife's employment } \\
\text { status }\end{array}$ & & $\begin{array}{l}-42.859 \star \star \\
(20.241)\end{array}$ & & $\begin{array}{l}-54.426^{\star} \\
(31.469)\end{array}$ & & $\begin{array}{l}-31.650 \\
(25.206)\end{array}$ \\
\hline Control variables & & & & & & \\
\hline Education (dummy) & no & no & no & no & no & no \\
\hline Age (dummy) & yes & yes & yes & yes & yes & yes \\
\hline $\begin{array}{l}\text { Industry and } \\
\text { Occupation } \\
\text { (dummy) }\end{array}$ & yes & yes & yes & yes & yes & yes \\
\hline Firm Size (dummy) & yes & yes & yes & yes & yes & yes \\
\hline Year (dummy) & yes & yes & yes & yes & yes & yes \\
\hline Observations & 12,824 & 12,824 & 4,262 & 4,262 & 8,562 & 8,562 \\
\hline$R^{2}$ & 0.013 & 0.014 & 0.015 & 0.016 & 0.017 & 0.018 \\
\hline
\end{tabular}

Note: Clustered robust standard errors in parentheses. Significance levels: *denotes $10 \%$; $\star \star 5 \%$; $\star \star \star ~ 1 \%$. 
Table 11: Effect of children on wages and labor supply among workers who does not change jobs during sample period.

\begin{tabular}{|c|c|c|c|c|c|c|}
\hline \multirow{2}{*}{$\begin{array}{l}\text { Log (real hourly) wage } \\
\text { Number of children }\end{array}$} & \multirow[b]{2}{*}{0.009} & \multirow[t]{2}{*}{ Full sample } & \multicolumn{2}{|c|}{ Born in 1960 or earlier } & \multicolumn{2}{|c|}{ Born after 1960} \\
\hline & & & -0.003 & & 0.007 & \\
\hline & $(0.009)$ & & $(0.020)$ & & $(0.010)$ & \\
\hline \multirow[t]{2}{*}{ One child } & & 0.022 & & 0.009 & & 0.022 \\
\hline & & $(0.015)$ & & $(0.028)$ & & $(0.016)$ \\
\hline \multirow[t]{2}{*}{ Two children } & & 0.027 & & -0.025 & & 0.029 \\
\hline & & $(0.020)$ & & $(0.039)$ & & $(0.022)$ \\
\hline \multirow[t]{2}{*}{ Three children } & & 0.026 & & 0.010 & & 0.008 \\
\hline & & $(0.027)$ & & $(0.047)$ & & $(0.032)$ \\
\hline \multirow[t]{2}{*}{ Four or more children } & 0.020 & 0.022 & $-0.254^{\star \star \star}$ & $-0.240^{\star \star \star}$ & 0.089 & 0.085 \\
\hline & $(0.059)$ & $(0.059)$ & $(0.088)$ & $(0.085)$ & $(0.054)$ & $(0.055)$ \\
\hline \multicolumn{7}{|l|}{$F$-tests: } \\
\hline \multicolumn{7}{|l|}{ Two children - one } \\
\hline child & & 0.005 & & -0.034 & & 0.007 \\
\hline Three children - two & & $\{0.20\}$ & & $\{0.94\}$ & & $\{0.31\}$ \\
\hline children & & -0.001 & & 0.035 & & -0.021 \\
\hline Observations & 7,768 & 7,768 & 2,684 & 2,684 & 5,084 & 5,084 \\
\hline$R^{2}$ & 0.170 & 0.170 & 0.176 & 0.177 & 0.177 & 0.177 \\
\hline Annual hours worked & & Full sample & Born in 19 & 60 or earlier & & rn after 1960 \\
\hline \multirow[t]{2}{*}{ Number of children } & $35.748^{*}$ & & -46.867 & & $55.796^{\star \star}$ & \\
\hline & $(21.107)$ & & $(46.020)$ & & $(24.182)$ & \\
\hline \multirow[t]{2}{*}{ One child } & & 23.802 & & -81.675 & & 30.846 \\
\hline & & $(37.205)$ & & $(90.716)$ & & $(39.836)$ \\
\hline \multirow[t]{2}{*}{ Two children } & & 77.684 & & -102.045 & & $108.280^{\star *}$ \\
\hline & & $(48.575)$ & & (118.879) & & $(53.488)$ \\
\hline \multirow[t]{2}{*}{ Three children } & & 85.174 & & -170.249 & & $148.192^{\star}$ \\
\hline & & $(64.618)$ & & (137.776) & & $(76.452)$ \\
\hline \multirow[t]{2}{*}{ Four or more children } & $378.698^{\star \star \star}$ & $365.885^{\star \star \star}$ & 82.335 & 55.274 & $453.105^{\star \star *}$ & $441.070^{\star \star \star}$ \\
\hline & $(93.312)$ & $(93.214)$ & $(162.334)$ & $(162.182)$ & $(114.664)$ & $(114.736)$ \\
\hline \multicolumn{7}{|l|}{ F-tests: } \\
\hline Two children - one & & $53.882^{\star}$ & & -20.37 & & $77.434^{\star \star}$ \\
\hline child & & $\{2.74\}$ & & $\{0.07\}$ & & $\{4.70\}$ \\
\hline Three children - two & & 7.49 & & -68.204 & & 39.912 \\
\hline children & & $\{0.03\}$ & & $\{1.02\}$ & & $\{0.63\}$ \\
\hline Observations & 7,858 & 7,858 & 2,706 & 2,706 & 5,152 & 5,152 \\
\hline$R^{2}$ & 0.013 & 0.013 & 0.020 & 0.020 & 0.016 & 0.016 \\
\hline
\end{tabular}

Notes: Clustered robust standard errors in parentheses. F-statistics in curly brackets. Significance levels: ${ }^{\star}$ denotes $10 \% ;{ }^{\star \star} 5 \%$; ${ }^{\star \star \star} 1 \%$. All equations control for education (in case of OLS), age, industry, occupation, firm size, and year. This table provides results for the FE estimation only. 
Table 12: Effect of children on wages and labor supply when controlling for type of employment.

\begin{tabular}{|c|c|c|c|c|c|c|}
\hline \multirow{2}{*}{$\frac{\text { Log (real hourly) wage }}{\text { Number of children }}$} & \multirow{2}{*}{$\begin{array}{c}0.022^{\star \star \star} \\
(0.008)\end{array}$} & \multirow{2}{*}{ Full sample } & \multicolumn{2}{|c|}{ Born in 1960 or earlier } & \multicolumn{2}{|r|}{ Born after 1960} \\
\hline & & & $\begin{array}{c}0.037^{\star} \\
(0.020)\end{array}$ & & $\begin{array}{r}0.009 \\
(0.008)\end{array}$ & \\
\hline One child & & $\begin{array}{l}0.028^{\star \star} \\
(0.013)\end{array}$ & & $\begin{array}{r}0.040 \\
(0.054)\end{array}$ & & $\begin{array}{r}0.018 \\
(0.014)\end{array}$ \\
\hline Two children & & $\begin{array}{l}0.049^{\star \star \star *} \\
(0.017)\end{array}$ & & $\begin{array}{r}0.069 \\
(0.061)\end{array}$ & & $\begin{array}{r}0.025 \\
(0.018)\end{array}$ \\
\hline Three children & & $\begin{array}{l}0.067^{\star \star \star *} \\
(0.025)\end{array}$ & & $\begin{array}{l}0.114^{\star} \\
(0.067)\end{array}$ & & $\begin{array}{r}0.023 \\
(0.028)\end{array}$ \\
\hline Four or more children & $\begin{array}{r}0.016 \\
(0.061)\end{array}$ & $\begin{array}{r}0.017 \\
(0.061)\end{array}$ & $\begin{array}{l}-0.085 \\
(0.134)\end{array}$ & $\begin{array}{l}-0.082 \\
(0.139)\end{array}$ & $\begin{array}{r}0.041 \\
(0.050)\end{array}$ & $\begin{array}{r}0.041 \\
(0.050)\end{array}$ \\
\hline F-tests: & & & & & & \\
\hline $\begin{array}{l}\text { Two children - one } \\
\text { child }\end{array}$ & & $\begin{array}{l}0.021^{\star} \\
\{3.51\}\end{array}$ & & $\begin{array}{r}0.0290 \\
\{0.79\}\end{array}$ & & $\begin{array}{r}0.007 \\
\{0.36\}\end{array}$ \\
\hline $\begin{array}{l}\text { Three children - two } \\
\text { children }\end{array}$ & & $\begin{array}{r}0.0180 \\
\{1.22\}\end{array}$ & & $\begin{array}{r}0.0450 \\
\{2.34\}\end{array}$ & & $\begin{array}{r}-0.002 \\
\{0.01\}\end{array}$ \\
\hline $\begin{array}{l}\text { Regular employment } \\
\text { (dummy) }\end{array}$ & $\begin{array}{r}0.033 \\
(0.039)\end{array}$ & $\begin{array}{r}0.033 \\
(0.039)\end{array}$ & $\begin{array}{l}0.131^{\star \star} \\
(0.064)\end{array}$ & $\begin{array}{l}0.131^{\star \star} \\
(0.064)\end{array}$ & $\begin{array}{l}-0.021 \\
(0.046)\end{array}$ & $\begin{array}{l}-0.021 \\
(0.046)\end{array}$ \\
\hline Observations & 12,560 & 12,560 & 4,202 & 4,202 & 8,358 & 8,358 \\
\hline$R^{2}$ & 0.092 & 0.092 & 0.068 & 0.068 & 0.125 & 0.125 \\
\hline Annual hours worked & & Full sample & Born in 19 & 60 or earlier & & orn after 1960 \\
\hline Number of children & $\begin{array}{l}61.948^{\star \star \star} \\
(17.926)\end{array}$ & & $\begin{array}{l}-60.053 \\
(40.942)\end{array}$ & & $\begin{array}{l}86.058^{\star \star \star} \\
(20.079)\end{array}$ & \\
\hline One child & & $\begin{array}{l}74.211^{\star \star} \\
(32.198)\end{array}$ & & $\begin{array}{r}34.475 \\
(75.840)\end{array}$ & & $\begin{array}{l}78.559 * * \\
(34.636)\end{array}$ \\
\hline Two children & & $\begin{array}{l}158.349^{\star \star \star} \\
(40.798)\end{array}$ & & $\begin{array}{r}5.807 \\
(97.955)\end{array}$ & & $\begin{array}{l}187.711^{\star \star \star *} \\
(44.715)\end{array}$ \\
\hline Three children & & $\begin{array}{l}155.549^{\star * \star} \\
(56.607)\end{array}$ & & $\begin{array}{l}-134.118 \\
(120.711)\end{array}$ & & $\begin{array}{l}228.494^{\star \star \star *} \\
(64.797)\end{array}$ \\
\hline Four or more children & $\begin{array}{l}329.557^{\star \star \star} \\
(90.468)\end{array}$ & $\begin{array}{l}316.409^{* * *} \\
(91.651)\end{array}$ & $\begin{array}{l}-112.560 \\
(146.161)\end{array}$ & $\begin{array}{r}-50.626 \\
(143.904)\end{array}$ & $\begin{array}{l}447.655^{\star \star \star} \\
(118.373)\end{array}$ & $\begin{array}{l}431.994^{\star \star *} \\
(120.449)\end{array}$ \\
\hline F-tests: & & & & & & \\
\hline $\begin{array}{l}\text { Two children - one } \\
\text { child }\end{array}$ & & $\begin{array}{l}84.138^{\star \star *} \\
\{8.96\}\end{array}$ & & $\begin{array}{r}-28.6680 \\
\{0.22\}\end{array}$ & & $\begin{array}{l}109.152^{\star \star \star} \\
\{12.32\}\end{array}$ \\
\hline $\begin{array}{l}\text { Three children - two } \\
\text { children }\end{array}$ & & $\begin{array}{r}-2.8000 \\
\{0.01\}\end{array}$ & & $\begin{array}{c}-139.925^{\star} \\
\{3.53\}\end{array}$ & & $\begin{array}{r}40.783 \\
\{0.78\}\end{array}$ \\
\hline $\begin{array}{l}\text { Regular employment } \\
\text { (dummy) }\end{array}$ & $\begin{array}{l}394.395^{\star \star \star} \\
(76.144)\end{array}$ & $\begin{array}{l}393.366^{* \star *} \\
(76.018)\end{array}$ & $\begin{array}{l}315.145^{\star \star} \\
(131.781)\end{array}$ & $\begin{array}{l}311.136^{* *} \\
(131.273)\end{array}$ & $\begin{array}{l}428.342^{\star \star \star} \\
(90.404)\end{array}$ & $\begin{array}{l}427.896^{\star \star \star *} \\
(90.333)\end{array}$ \\
\hline Observations & 12,816 & 12,816 & 4,260 & 4,260 & 8,556 & 8,556 \\
\hline$R^{2}$ & 0.020 & 0.021 & 0.020 & 0.021 & 0.026 & 0.027 \\
\hline
\end{tabular}

Notes: Clustered robust standard errors in parentheses. F-statistics in curly brackets. Significance levels: ${ }^{\star}$ denotes $10 \%$; ${ }^{\star \star} 5 \%$; ${ }^{\star \star *} 1 \%$. All equations control for education (in case of OLS), age, industry, occupation, firm size, and year. This table provides results for the FE estimation only. 
Table 13: Effect of children on labor supply when controlling for the measure of wealth.

\begin{tabular}{|c|c|c|c|c|c|c|}
\hline \multirow{2}{*}{$\begin{array}{l}\text { Annual hours } \\
\text { worked } \\
\text { Number of children }\end{array}$} & & \multirow[t]{2}{*}{ Full sample } & \multicolumn{2}{|c|}{ Born in 1960 or earlier } & \multicolumn{2}{|r|}{ Born after 1960} \\
\hline & $\begin{array}{l}65.866^{\star \star \star} \\
(18.540)\end{array}$ & & $\begin{array}{l}-75.938^{\star} \\
(39.696)\end{array}$ & & $\begin{array}{l}92.623^{\star \star \star} \\
(20.995)\end{array}$ & \\
\hline One child & & $\begin{array}{l}104.352^{\star \star \star} \\
(34.547)\end{array}$ & & $\begin{array}{r}47.843 \\
(77.227)\end{array}$ & & $\begin{array}{l}106.609 * * * \\
(37.287)\end{array}$ \\
\hline Two children & & $\begin{array}{l}181.742^{\star \star \star} \\
(42.925)\end{array}$ & & $\begin{array}{l}-20.326 \\
(96.195)\end{array}$ & & $\begin{array}{l}214.267^{\star \star \star} \\
(47.259)\end{array}$ \\
\hline Three children & & $\begin{array}{l}175.634^{\star \star \star} \\
(57.955)\end{array}$ & & $\begin{array}{l}-150.589 \\
(117.384)\end{array}$ & & $\begin{array}{l}248.325^{\star * \star} \\
(67.592)\end{array}$ \\
\hline $\begin{array}{l}\text { Four or more } \\
\text { children }\end{array}$ & $\begin{array}{l}316.234^{\star \star \star} \\
(101.493)\end{array}$ & $\begin{array}{l}312.782^{\star \star \star} \\
(102.967)\end{array}$ & $\begin{array}{l}-187.164 \\
(138.933)\end{array}$ & $\begin{array}{r}-99.178 \\
(138.438)\end{array}$ & $\begin{array}{l}445.302^{\star \star \star} \\
(140.035)\end{array}$ & 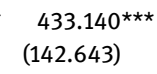 \\
\hline F-tests: & & & & & & \\
\hline $\begin{array}{l}\text { Two children - } \\
\text { one child }\end{array}$ & & $\begin{array}{l}77.39 \star \star \star \star \\
\{7.39\}\end{array}$ & & $\begin{array}{r}-68.169 \\
\{1.21\}\end{array}$ & & $\begin{array}{c}107.658^{\star \star \star} \\
\{11.17\}\end{array}$ \\
\hline $\begin{array}{c}\text { Three children - } \\
\text { two children }\end{array}$ & & $\begin{array}{r}-6.108 \\
\{0.02\}\end{array}$ & & $\begin{array}{c}-130.263^{\star \star} \\
\{3.89\}\end{array}$ & & $\begin{array}{r}34.058 \\
\{0.51\}\end{array}$ \\
\hline Log of savings & $\begin{array}{l}12.470^{\star \star} \\
(5.036)\end{array}$ & $\begin{array}{l}12.069^{\star \star} \\
(5.038)\end{array}$ & $\begin{array}{l}-0.464 \\
(9.250)\end{array}$ & $\begin{array}{r}-0.983 \\
(9.219)\end{array}$ & $\begin{array}{l}19.214^{\star \star \star} \\
(5.841)\end{array}$ & $\begin{array}{l}19.214^{\star \star \star \star} \\
(5.841)\end{array}$ \\
\hline Log of portfolio & $\begin{array}{l}-3.873 \\
(7.132)\end{array}$ & $\begin{array}{l}-4.113 \\
(7.148)\end{array}$ & $\begin{array}{l}-9.058 \\
(9.734)\end{array}$ & $\begin{array}{l}-9.186 \\
(9.738)\end{array}$ & $\begin{array}{r}-0.400 \\
(10.056)\end{array}$ & $\begin{array}{r}-0.400 \\
(10.056)\end{array}$ \\
\hline Observations & 11,895 & 11,895 & 3,938 & 3,938 & 7,957 & 7,957 \\
\hline$R^{2}$ & 0.016 & 0.02 & 0.019 & 0.019 & 0.022 & 0.022 \\
\hline
\end{tabular}

Notes: Clustered robust standard errors in parentheses. F-statistics in curly brackets. Significance levels: * denotes $10 \%$; ${ }^{\star \star} 5 \%$; ${ }^{\star \star \star} 1 \%$. All equations control for education (in case of OLS), age, industry, occupation, firm size, and year. This table provides results for the FE estimation only.

Table 14: Effect of children on (log real hourly) wages and labor supply by cohort.

\begin{tabular}{|c|c|c|c|c|c|c|}
\hline \multirow{2}{*}{$\begin{array}{l}\text { Log (real hourly) wage } \\
\text { Number of children }\end{array}$} & \multicolumn{2}{|c|}{ Born in 1960 or earlier } & \multicolumn{2}{|c|}{$\begin{array}{r}\text { Born between } 1961 \text { and } \\
1965\end{array}$} & & Born after 1965 \\
\hline & $\begin{array}{l}0.039 * \\
(0.021)\end{array}$ & & $\begin{array}{l}0.037^{\star \star \star} \\
(0.014)\end{array}$ & & $\begin{array}{l}-0.008 \\
(0.010)\end{array}$ & \\
\hline One child & & $\begin{array}{r}0.045 \\
(0.053)\end{array}$ & & $\begin{array}{r}0.017 \\
(0.032)\end{array}$ & & $\begin{array}{r}0.011 \\
(0.015)\end{array}$ \\
\hline Two children & & $\begin{array}{r}0.077 \\
(0.061)\end{array}$ & & $\begin{array}{r}0.054 \\
(0.037)\end{array}$ & & $\begin{array}{r}0.001 \\
(0.021)\end{array}$ \\
\hline Three children & & $\begin{array}{c}0.122^{\star} \\
(0.067)\end{array}$ & & $\begin{array}{l}0.105^{\star \star} \\
(0.047)\end{array}$ & & $\begin{array}{l}-0.052 \\
(0.035)\end{array}$ \\
\hline Four or more children & $\begin{array}{l}-0.078 \\
(0.136)\end{array}$ & $\begin{array}{l}-0.073 \\
(0.140)\end{array}$ & $\begin{array}{r}0.080 \\
(0.071)\end{array}$ & $\begin{array}{r}0.072 \\
(0.073)\end{array}$ & $\begin{array}{r}0.021 \\
(0.069)\end{array}$ & $\begin{array}{r}0.008 \\
(0.072)\end{array}$ \\
\hline$F$-tests: & & & & & & \\
\hline Two children - one child & & $\begin{array}{r}0.0320 \\
\{0.94\}\end{array}$ & & $\begin{array}{l}0.037^{\star} \\
\{3.67\}\end{array}$ & & $\begin{array}{r}-0.010 \\
\{0.46\}\end{array}$ \\
\hline
\end{tabular}


Table 14: (Continued)

\begin{tabular}{|c|c|c|c|c|c|c|}
\hline \multirow{2}{*}{$\begin{array}{l}\text { Log (real hourly) wage } \\
\text { Three children - two } \\
\text { children }\end{array}$} & \multicolumn{2}{|c|}{ Born in 1960 or earlier } & \multicolumn{2}{|c|}{$\begin{array}{r}\text { Born between } 1961 \text { and } \\
1965\end{array}$} & \multicolumn{2}{|r|}{ Born after 1965} \\
\hline & & $\begin{array}{r}0.0450 \\
\{2.23\}\end{array}$ & & $\begin{array}{l}0.051^{\star} \\
\{3.21\}\end{array}$ & & $\begin{array}{l}-0.053^{\star \star} \\
\{4.17\}\end{array}$ \\
\hline Observations & 4,204 & 4,204 & 3,605 & 3,605 & 4,758 & 4,758 \\
\hline$R^{2}$ & 0.064 & 0.065 & 0.143 & 0.143 & 0.124 & 0.126 \\
\hline Annual hours worked & Born in 19 & 60 or earlier & Born betw & $\begin{array}{r}\text { en } 1961 \text { and } \\
1965 \\
\end{array}$ & & Born after 1965 \\
\hline Number of children & $\begin{array}{l}-44.279 \\
(42.208)\end{array}$ & & $\begin{array}{c}60.745^{\star} \\
(33.657)\end{array}$ & & $\begin{array}{l}106.164^{\star \star \star} \\
(24.732)\end{array}$ & \\
\hline One child & & $\begin{array}{r}58.131 \\
(79.774)\end{array}$ & & $\begin{array}{r}110.457 \\
(89.147)\end{array}$ & & $\begin{array}{l}77.064^{\star \star} \\
(37.926)\end{array}$ \\
\hline Two children & & $\begin{array}{r}46.417 \\
(102.095)\end{array}$ & & $\begin{array}{c}181.665^{\star} \\
(100.313)\end{array}$ & & $\begin{array}{l}218.144^{\star \star \star} \\
(51.296)\end{array}$ \\
\hline Three children & & $\begin{array}{r}-82.385 \\
(128.483)\end{array}$ & & $\begin{array}{c}184.522^{\star} \\
(111.370)\end{array}$ & & $\begin{array}{l}285.277^{\star \star \star \star} \\
(90.525)\end{array}$ \\
\hline Four or more children & $\begin{array}{l}-66.698 \\
(150.013)\end{array}$ & $\begin{array}{r}0.562 \\
(150.416)\end{array}$ & $\begin{array}{l}342.321^{\star \star} \\
(140.134)\end{array}$ & $\begin{array}{l}358.089^{\star \star} \\
(152.694)\end{array}$ & $\begin{array}{l}511.014^{\star \star} \\
(204.957)\end{array}$ & $\begin{array}{l}491.370^{* *} \\
(208.525)\end{array}$ \\
\hline F-tests: & & & & & & \\
\hline Two children - one child & & $\begin{array}{r}-11.714 \\
\{0.04\}\end{array}$ & & $\begin{array}{r}71.208 \\
\{2.03\}\end{array}$ & & $\begin{array}{l}141.08^{\star \star \star} \\
\{13.00\}\end{array}$ \\
\hline $\begin{array}{l}\text { Three children - two } \\
\text { children }\end{array}$ & & $\begin{array}{c}-128.802^{\star} \\
\{2.81\}\end{array}$ & & $\begin{array}{r}2.857 \\
\{0.00\}\end{array}$ & & $\begin{array}{l}67.133 \\
\{0.83\}\end{array}$ \\
\hline Observations & 4,262 & 4,262 & 3,698 & 3,698 & 4,864 & 4,864 \\
\hline$R^{2}$ & 0.015 & 0.016 & 0.024 & 0.025 & 0.022 & 0.022 \\
\hline
\end{tabular}

Notes: Clustered robust standard errors in parentheses. F-statistics in curly brackets. Significance levels: * denotes $10 \%$; ${ }^{\star *} 5 \%$; ${ }^{\star \star *} 1 \%$. All equations control for education (in case of OLS), age, industry, occupation, firm size, and year. This table provides results for the FE estimation only. 
(a)

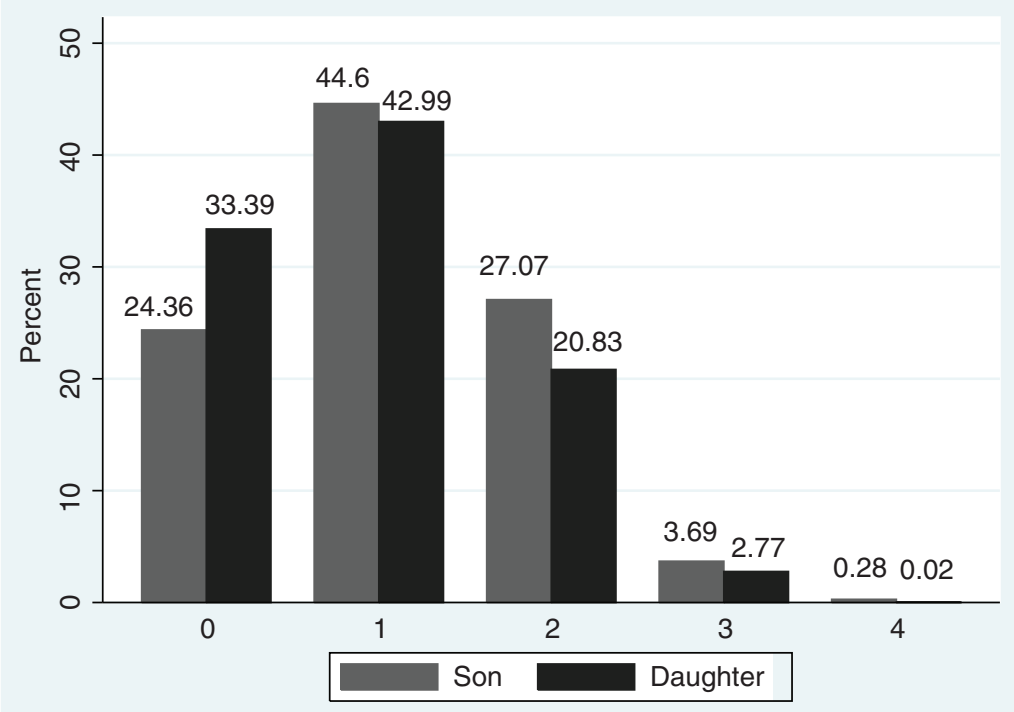

(b)

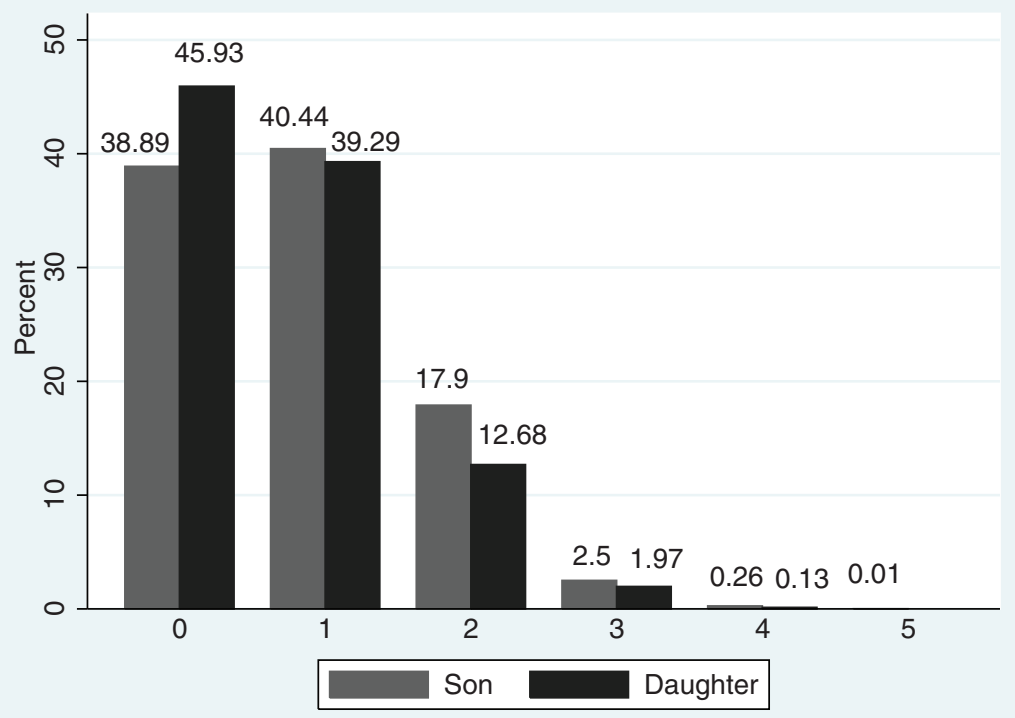

Figure 4: Distribution of number of sons and daughters. (a) Born before 1960, (b) Born after 1960. 


\section{References}

Abe, Y. 2011. "The Equal Employment Opportunity Law and Labor Force Behavior of Women in Japan." Journal of the Japanese and International Economies 25:39-55.

Abe, Y. 2012. "A Cohort Analysis of Male Labor Supply in Japan." Journal of the Japanese and International Economies 26:23-43.

Angrist, J., and W. Evans. 1998. "Children and Their Parents' Labor Supply: Evidence from Exogeneous Variation in Family Size." American Economic Review 88(3):450-77.

Arnold, F., and Z. Liu. 1986. "Son Preference, Fertility and Family Planning in China." Population and Development Review 12(2):221-46.

Becker, G. S. 1985. "Human Capital, Effort, and the Sexual Division of Labor." Journal of Labor Economics 3(1):33-58.

Burgess, S. (1999). The reallocation of labour: an international comparison using job tenure. CEP Discussion Paper no. 416.

Choi, H. J., J. Joesch, and S. Lundberg. 2008. "Sons, Daughters, Wives, and the Labour Market Outcomes of West German Men.” Labour Economics 15(5):795-811.

Chung, W., and M. D. Gupta. 2007. "The Decline of Son Preference in South Korea: The Roles of Development and Public Policy.” Population and Development Review 33(4): 757-83.

Das Gupta, M., J. Zhenghua, L. Bohua, X. Zhenming, W. Chung, and B. Hwa-Ok. 2003. "Why Is Son Preference so Persistent in East and South Asia? A Cross-Country Study of China, India and the Republic of Korea." Journal of Development Studies 40(2):153-87.

Das, N. 1984. "Sex Preference Pattern and Its Stability in India: 1970-1980." Demography India 13:108-19.

Edwards, L., and M. Pasquale. 2003. "Women's Higher Education in Japan: Family Background Economic Factors and the Equal Employment Opportunity Law." Journal of the Japanese and International Economies 17(1):1-32.

Genda, Y., A. Kondo, and S. Ohta. 2010. "Long-Term Effects of a Recession at Labor Market Entry in Japan and the United States." Journal of Human Resources 45(1):157-96.

Halvorsen, R., and R. Palmquist. 1980. "The Interpretation of Dummy Variables in SemiLogarithmic Equations." American Economic Review 70:474-5.

Higuchi, Y. 2007. "Support for Continuing Work of Women: The Effect of Law and the Effect of Economic Condition." Mita Shogaku Kenkyu 50(5):45-66, in Japanese.

Kawaguchi, A. 2001. "Marriage Premium of Women: Impact of Marriage and Childbirth on Labor Force Participation and Wages." Kikan Kakei Keizai Kenkyu 51:63-71, in Japanese.

Kawaguchi, A. 2005a. "How Marriage and Child Birth Affect Wages of Male and Female Workers?." Nihon Rodo Kenkyu Zasshi 535:42-55, in Japanese.

Kawaguchi, A. 2005b. "The Cause of Decreasing Gender Wage Gap in the 1990s." Keizai Bunseki 175:52-82, in Japanese.

Kondo, A. 2007. "Does the first Job Really Matter? State Dependency in Employment Status in Japan." Journal of the Japanese and International Economies 21:379-402.

Kondo, A. 2008. "Long-term effects of recession when women entering labor markets in Japan and in the US" Kikan Kakei Keizai Kenkyu 70:73-80, in Japanese.

Korenman, S., and D. Neumark. 1991. "Does Marriage Really Make Men More Productive?." Journal of Human Resources 26(2):282-307. 
Korenman, S., and D. Neumark. 1992. "Marriage, Motherhood and Wages." Journal of Human Resources 27(2):233-55.

Kureishi, W., and M. Wakabayashi. 2011. "Son Preference in Japan." Journal of Population Economics 24(3):873-93.

Larsen, U., W. Chung, and M. D. Gupta. 1998. "Fertility and Son Preference in Korea." Population Studies 52(3):317-25.

Lundberg, S., and E. Rose. 2000. "Parenthood and the Earnings of Married Men and Women." Labour Economics 7(6):689-710.

Lundberg, S., and E. Rose. 2002. "The Effects of Sons and Daughters on Men's Labor Supply and Wages." The Review of Economics and Statistics 84(2):251-68.

Morita, Y. 2006. “The Effect of Low Fertility Rate on Firm Attitude." Nihon Rodo Kenkyu Zasshi 553:4-18, in Japanese.

Nagase, N. 1999. "Reasons for Low Fertility Rates: Working Conditions or Changing Attitudes.” Journal of Population Problems 55:1-18, in Japanese.

Sasajima, Y. (2009). Why Does Wage Include Various Benefits?. Nihon Rodo Kenkyu Zasshi, $585,26-9$, in Japanese.

Sousa-Poza, A., and F. Henneberger. 2004. "Analyzing Job Mobility with Job Turnover Intentions: An International Comparative Study." Journal of Economic Issues 38(1):113-37.

Waldfogel, J. 1995. "The Price of Motherhood: Family Status and Women's Pay in a Young British Cohort." Oxford Economic Paper 47(4):584-610.

Waldfogel, J. 1997. "The Effect of Children on Women's Wages." American Sociological Review 62(2):209-17.

Waldfogel, J. 1998. "The Family Gap for Young Women in the U.S. and Britain: Can Maternity Leave Make a Difference?." Journal of Labor Economics 16(3):505-54. 